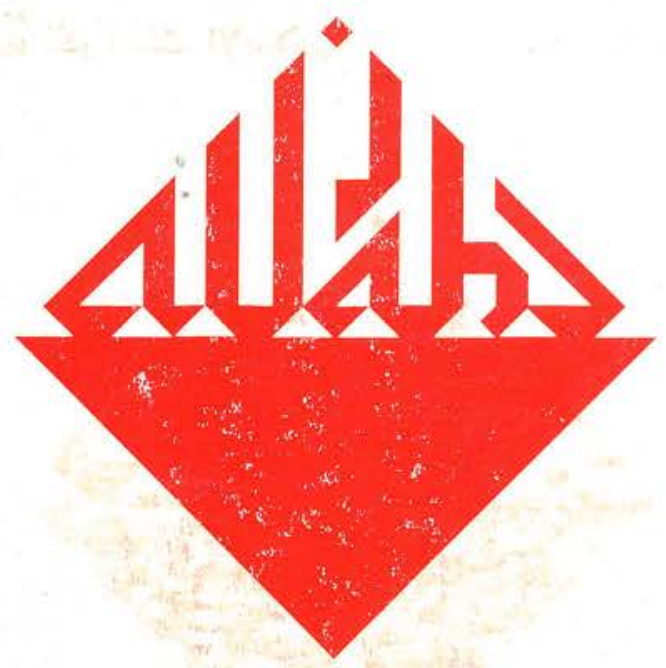

THE ULAMA IN ACEH:

A BRIEF HISTORICAL SURVEY

Yusny Saby

A SUDANESE SCHOLAR IN THE DIASPORA:

LIFE AND CAREER OF AHMAD MUHAMMAD

AL-SURKITTÎ IN INDONESIA (1911-1943)

Ahmed Ibrahim Abushouk

THE MEANING INTERPRETED:

THE CONCEPT OF BARAKAH IN ZIARAH

Jamhari 


\section{STIDLA ISLAIIIKK}

Indonesian Journal for Islamic Studies

Vol. 8, no. 1,2001

EDITORIAL BOARD:

M. Quraish Shihab (IAIN Jakarta)

Taufik Abdullah (LIPI Jakarta)

Nur A. Fadhil Lubis (IAIN Sumatra Utara)

M.C. Ricklefs (Melbourne University)

Martin van Bruinessen (Utrecht University)

John R. Bowen (Washington University, St. Louis)

M. Atho Mudzhar (IAIN Yogyakarta)

M. Kamal Hasan (International Islamic University, Kuala Lumpur)

EDITOR-IN-CHIEF

Azyumardi Azra

\section{EDITORS}

Johan H. Meuleman

Jajat Burhanuddin

Fuad Jabali

Jamhari

Oman Fathurahman

\section{ASSISTANT TO THE EDITORS}

Heni Nuroni

ENGLISH LANGUAGE ADVISOR

Richard G. Kraince

ARABIC LANGUAGE ADVISORS

Nursamad

\section{COVER DESIGNER}

\section{S. Prinka}

STUDIA ISLAMIKA (ISSN 0215-0492) is a journal published quarterly by the Center for the Study of Islam and Society (PPIM), IAIN Syarif Hidayatullah, Jakarta (STT DEPPEN No. 129/SK/DITJEN/PPG/STT/1976) and sponsored by the Department of Religious Affairs of the Republic of Indonesia. It specializes in Indonesian Islamic studies, and is intended to communicate original researches and current issues on the subject. This journal warmly welcomes contributions from scholars of related disciplines.

All articles published do not necessarily represent the views of the journal, or other institutions to which it is affiliated. They are solely the views of the authors. The articles contained in this journal have been refereed by the Board of Editors.

STUDIA ISLAMIKA has been accredited by The Ministry of National Education, Republic of Indonesia as an academic journal. 


\title{
The Meaning Interpreted: The Concept of Barakah in Ziarah
}

\begin{abstract}
Abstraksi: Perbincangan masalah ziarah di Jawa tampaknya masib tetap menarik. Tidak saja menarik jika dilihat dari berbagai macam interpretasi dan ritual yang dipraktekkan orang ketika melakukan ziarah, tetapi juga jika dilihat dari bagaimana masyarakat memahami konsep-konsep keaga-maan dalam kerangka Islam lokal. Praktek ziarab ke makam-makam orang-orang suci Islam (wali) sesunggubnya merupakan refleksi pemahaman keislaman. Misalnya saja, ketika mereka menjelaskan kedudukan wali di mata Tuban dan Manusia sangat terkait dengan pemahaman keagaman. Juga misalnya dalam mengartikan barakah, faktor yang penting dan menjadi inti dari parktek ziarah, mencerminkan realitas pemabaman keislaman. Artikel ini membahas tentang pemberian makna barakab berdasarkan pada praktek ziarab ke Sunan Tembayat di Bayat Klaten. Ternyata makna barakah,
\end{abstract} setidaknya dari apa yang ditemui di Bayat, sungguh sangat beragam.

Di Bayat orang membedakan antara "barakah" dan "perolehan". Bara$k a h$ adalah hasil yang didapat setelah melakukan ziarah. Barakah berasal dari Tuhan, baik langsung atau melalui perantaraan Wali, yang memberikan manfaat pada ketenangan jïwa. Selain itu, barakah, seperti balnya pabala yang didapat ketika melakukan ibadah, akan bermanfaat pada hari ki. amat nanti. Sementara itu, "perolehan" adalab hasil yang didapat dari ziarah yang bersifat duniawi. Termasuk dalam kategori perolehan ini adalab "sesuatu" yang dapat dimanfaatkan untuk mencari kekayaan, menarik lawan jenis, sukses dalam berbisnis maupun sekolah, dan semacamnya. Jadi, bagi peziarah di Bayat, barakab bersifat suci dan mungkin saja didapat tidak kasat mata, sedangkan "perolehan" bersifat bersifat duniawi. Tidak seperti barakah, perolehan mempunyai sifat "panas" yang dapat membahayakan manusia yang mencarinya.

Perbedaan makna dan karakteristik barakab tersebut juga mempengarubi ritual yang dilakukan untuk mendapatkannya. Barakab diperoleh de- 
ngan melakukan ritual sebagaimana ibadab lain, seperti membaca Qur'an, tablil ataupun zikir. Sementara itu, perolehan juga mempunyai cara ritual sendiri, misalnya melakukan meditasi di suatu tempat secara terus menerus. Di samping itu, perbedaan barakah juga mempengarubi peziarah dalam memberikan makna terhadap simbol-simbol yang dipakai dalam ziarah, seperti bunga, air dan kemenyan (dupa). Misalnya, dalam menginterpretasikan fungsi kemenyan, sebagian menganggapnya sebagai alat perwangi dan pengusir serangga yang pasti banyak di tempat-tempat ziarah. Namun sebagian peziarah percaya babwa kemenyan adalab makanan kesukaan rob-roh. Sementara yang lain menganggap kemenyan hanyalab simbol ajaran bagi manusia babrwa memanjatkan do'a haruslab ke atas, seperti yang dilambangkan oleh asap kemenyan yang terbang ke udara.

Barakah dan perolehan seringkali diberikan lewat tanda-tanda (ngalamat) yang perlu diinterpretasikan. Tanda-tanda itu bisa datang lewat mimpi, atau tanda-tanda alam yang khusus. Oleb karena itu, peziarab perlu menafsirkan tanda-tanda tersebut yang seringkali memerlukan bantuan orang lain. Dalam menerjemabkan makna ngalamat tersebut, juru kunci makam sang wali mempunyai peran yang sangat penting. Karena dianggap sebagai keturunan wali-kebanyakan juru kunci adalab keturunan dari sang walijuru kunci dapat menerjemabkan ngalamat yang diberikan oleh wali lewat mimpi atau tanda-tanda alam kbusus. Di samping itu, peziarah menafsirkan tanda-tanda dengan mendiskusikannya dengan sesama peziarah yang mungkin pernah mendapat ngalamat yang sama. Cerita tentang peziarah yang sukses setelab melakukan ziarah sering terdengar dalam perbincangan antarpeziarah.

Juru kunci dengan demikian memegang peran yang penting dalam proses ziarah. Tidak saja ia berperan sebagai penjaga fisik kuburan, tetapi dia merupakan wakil dan sekaligus penerjemah dari ziarah dan barakab. Terlebih dari itu, juru kunci mempunyai peran sebagai agen untuk tetap menjaga tradisi ziarah. Lewat-lewat terjemahan dan interpretasinya, juru kunci sesunggubnya melakukan transformasi tradisi ziarah. Cerita-cerita tentang kebesaran wali, diproduksi kembali untuk melegitimasi kesakralan tempat ziarah. Dalam menerjemabkan ngalamat, apakah itu sebagai barakah atau perolehan, juru kunci sesunggubnya telab berperan sebagai agent Islam lokal. Dengan posisi yang penting itu, tidak mengherankan jika pada makammakam suci tertentu juru kunci dipilib secara ketat.

Interpretasi makna barakah dan perbedaan ritual dalam memperolehnya menggambarkan betapa beragamnya Muslim Jawa memabami Islam. Perbedaan-perbedaan itu merupakan bukti babrwa Islam lokal mempunyai multi suara (multi-voices). 


\section{The Meaning Interpreted: The Concept of Barakah in Ziarah}

خلاصة: والكلام عن الزيارة في جاوه مازال مهتما به حتى اليوم، و لم تكن مهمته الماته

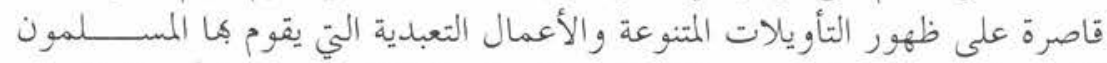

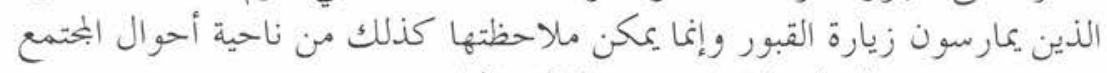

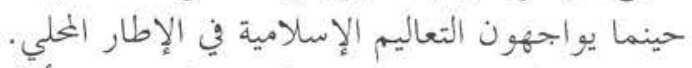

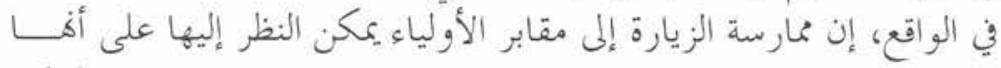

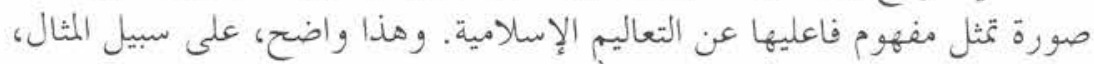

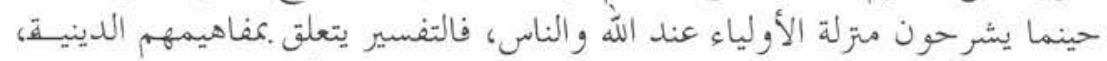

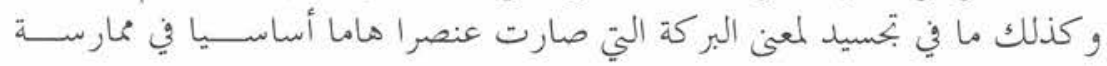

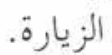

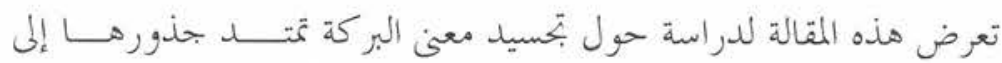

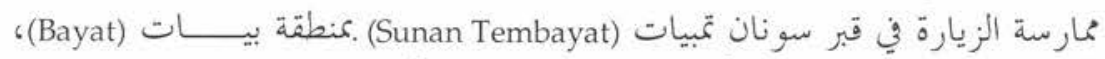

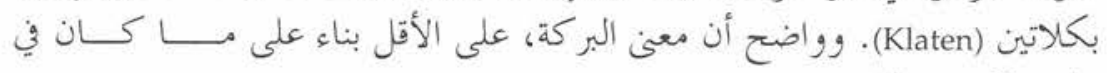

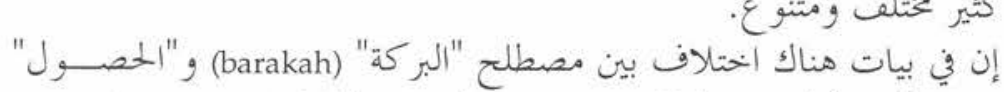

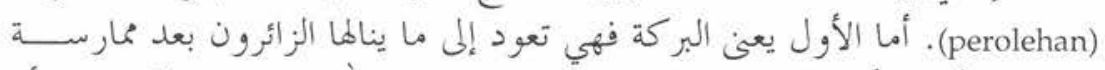

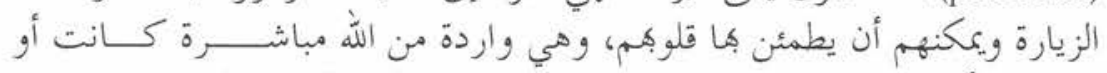

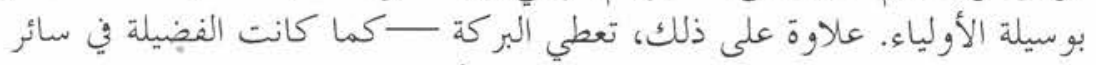

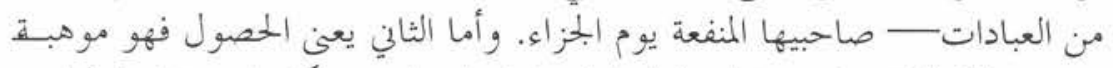

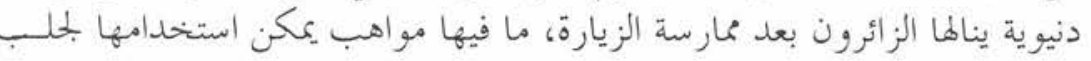




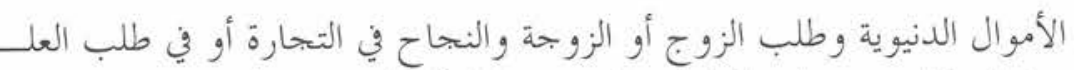

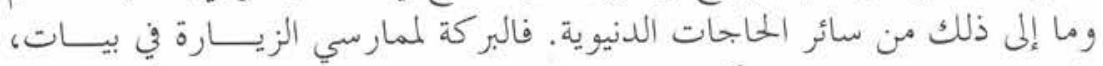

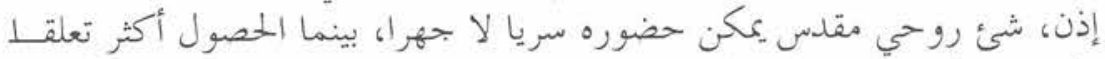

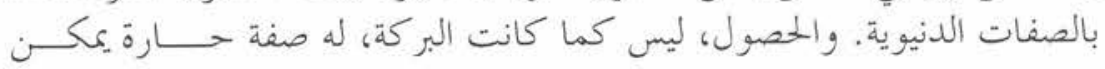
احتمال صاحبيها إلى المشقة. والحصن.

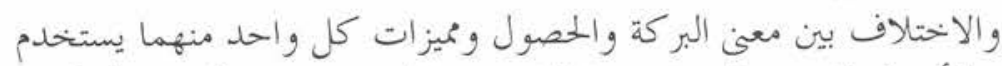

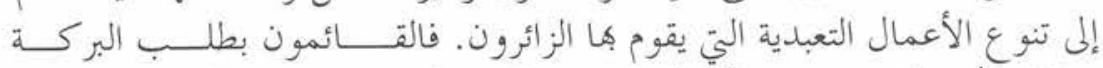

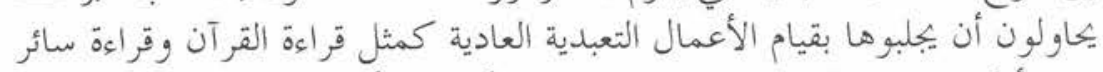

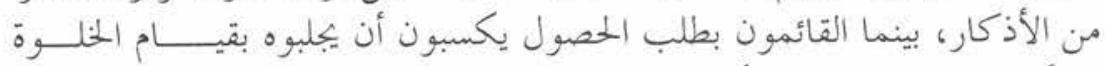

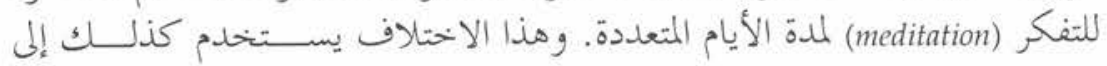

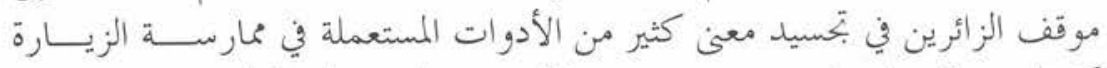

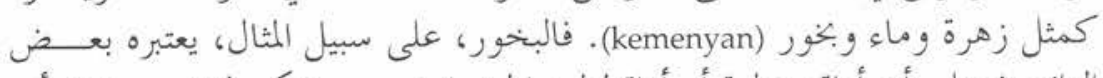

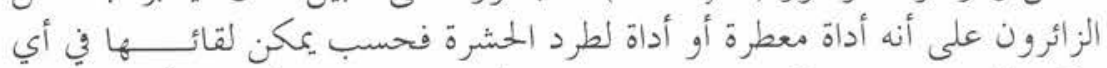

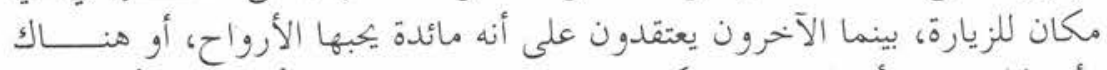

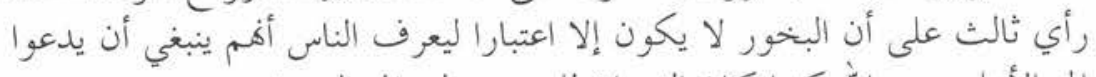

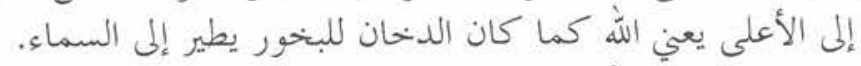

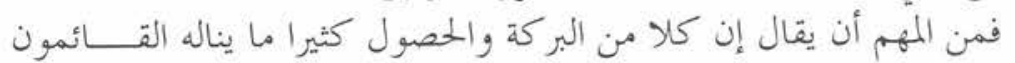

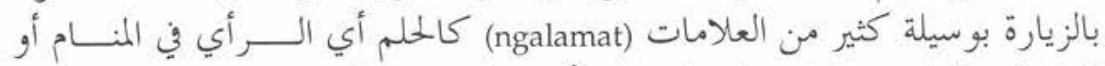

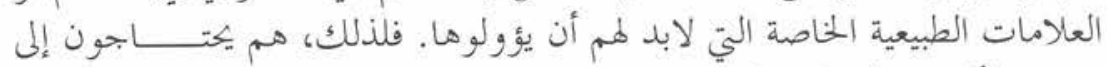

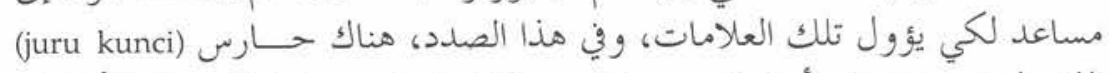

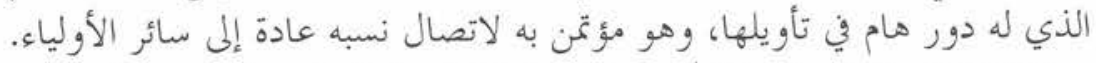

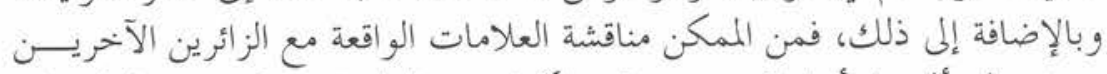

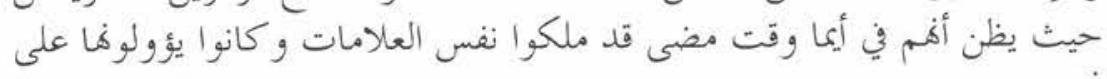
فالحاصل، إن للحارس وظيفة هامة بل حاسمة في ممارسة الزيارة، و لم تكن نحو صحيح

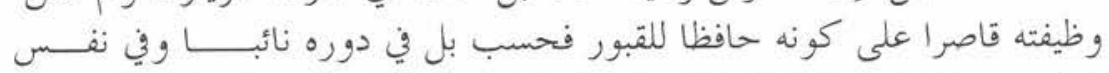

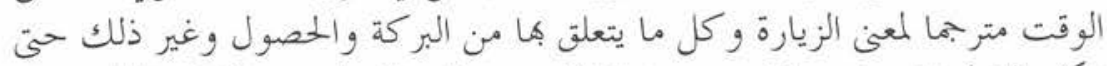

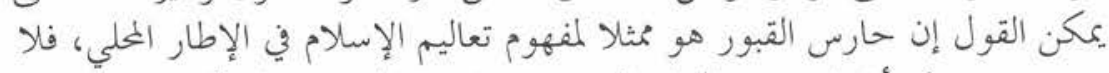

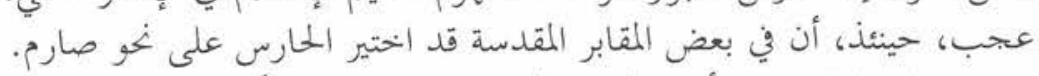

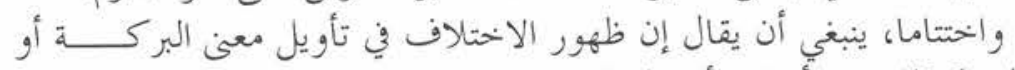

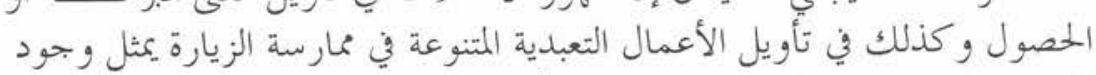

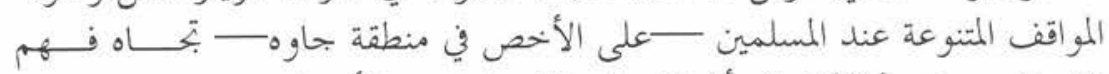
الإسلام، ويشير كذلك إلى أن الإسلام المحلي له تعدد الأصوات في الأحس (multi-voices). 
7 his article deals with the socio-religious traditions of Javanese Muslims practicing ziarab rituals-visit to sacred tombs. Ziarah 1 practice, especially to sacred tombs of Muslim Sufis, is regarded ibadab (pious acts). This article, based on ziarah practice to Sunan Tembayat in Klaten, examines the notion of barakab (god's blessing), one of the most salient aspects of ziarab ritual, in the frame of popular beliefs. Focusing on the presence of the diverse interpretations of barakah, it evaluates changes in the way in which Javanese Muslim understand religion as reflected in their interpretation of barakah.

It is argued by people who practice ziarah that barakah is the most important value of ziarah. When visitors to sacred tombs perform certain rituals, such as reciting Qur'ân, dhikr, tablîl and meditation in their ziarah, they ask for barakab from the wali. However, people differ in the way in which they explain what the meaning of barakab. Some argue that the barakab is god's reward (pabala), transmitted through the wali. Other argues that the barakah derives from the wali, as he/she is close to God.

In addition, in terms of religious beliefs, barakab is also characterized differently. In Bayat, where the fieldwork of this study was conducted, barakah is differentiated between, what people call as "barakab" (pure barakab) and "perolehan" (profane barakab). "Pure Barakah" is a reward of ziarab that will benefit people spiritually. This kind of barakab will not harm the people. On the other hand, perolehan is a worldly barakah, meaning barakah that will be used for worldly purposes. As the meaning of barakab is explained differently, the meaning of symbols involved in the ziarah, such as flowers, water and incense varies.

This article is a continuation of an article, "in the Center of Meaning," published in Studia Islamika vol 7 No. 1, 2000. The first article provided an introduction on ziarah practice in Java and the variation of the understanding of Wali. The variation of the meaning of barakab elaborated in this present article is a reflection of the polyphonic understanding of Islam in Java. Barakah, the core religious concept in ziarah practice, then is a window to see how people articulate their religious understandings. This article will also discuss about the importance of the juru kunci in assisting and interpreting ziarab ritual and barakah. The roles of ziarah rituals can be viewed from a functionalist stand which maintains that belief, and particularly ritual, reinforce the traditional social ties between individuals; it stresses the way in which the social structure of a group is strengthened and per- 
petuated through the ritualistic or mystic symbolization of the underlying social values upon which it rests (Morris, 1987).

\section{The role of Juru Kunci}

The term juru kunci consists of the two Javanese words, juru, meaning a master, and kunci meaning a key. Thus, the term juru kunci signifies a person or a custodian who looks after the key of a sacred place or building, such as a palace or a graveyard. The juru kunci play an important role in ziarah sites. Not only are juru kunci custodians of the location, but they also play a major role in performing ziarah. Juru kunci are the central figures in the interpretation of signs (ngalamat) gained in dreams, which are believed to be the clue of barakah. The juru kunci's role in the interpretation of ngalamat constitutes the fundamental element of the transmission of barakab.

The juru kunci, as the custodians of the graveyard, look after and maintain the graveyard complex and its various buildings. The Bayat graveyard is regarded as an important traditional complex that should be preserved. The graveyard's complex contains historical inscriptions about the Bayat region. The Panemut gate, for example, contains inscription about the time of the graveyard's renovation. Unfortunately, some of these inscriptions were destroyed due to human error and ignorance. Juru kunci also maintain the sacredness and the purity of the place, as there are a lot of people who come to perform ziarah. Bayat's visitors can be categorized into two groups, those who want merely to observe the place and those who wish to perform ziarah. Juru kunci provide guidance, explaining the story and describing the meanings of the place to the first group, while for the latter, the juru kunci give assistance in performing ziarab. In relation to this second function, juru kunci argue that their assistance in performing ziarah has heavy consequences, for Allah and for visitors.

Juru kunci, especially the juru kunci jero, assist visitors in ziarah rituals, including the interpretation of ngalamat. There are several activities that can only be done in the presence of a juru kunci. The first is the jawab ritual. In this ritual juru kunci play a major role. Juru kunci will lead the ritual, including asking permission to Sunan Tembayat, and reciting prayers. Second, the entry to the main building of Sunan Tembayat's tomb as it is always locked, and only Juru kunci have access to the key. Third, at the hajat slametan-a slametan held to mark the seventh ziarab- ${ }^{1}$ the juru kunci are the focus of the 
activity. As in the jawab ritual, juru kunci in the hajat slametan will lead the reciting prayers, declaring the visitors' intention and distributing the slametan.

Juru kunci play a significant role in the interpretation of ngalamat received from the Sunan, as visitors are generally unable to elucidate the message of the ngalamat. Sunan Tembayat gives ngalamat in several forms, such as in dreams, natural signs, greget (feelings) and so forth. However, most ngalamat are transmitted through dreams. Visitors believe that juru kunci, because they are abdi (servant) and descendants of Sunan, and because they spend so much time in the graveyard, are the appropriate interpreters of the Sunan Tembayat's ngalamat. This is one story told by a young boy who came to Bayat to search for an amulet:

"I came to Bayat because I was urged by a pious man in my dream. I could not recognize the person clearly. The man told me that Bayat is the right place to search for an amulet. After performing ziarah to the Sunan, I slept in the corner of the main building of Sunan Tembayat's tomb. A person with a nice smile and wearing white clothes approached me. He did not say anything to me, but he gave me a hoe. I did not understand the meaning of this symbol. Therefore, I asked Juru kunci to explain the ngalamat."

A Juru kunci tried to interpret the dream by referring to another visitor who had a similar dream. He said,

"Actually, it is difficult to know the exact meaning of a dream. However, I believe that Sunan Tembayat advises visitors through the dream. Thus, a dream, for me, is a symbol which should be interpreted to grasp the barakab. There are several ways to interpret symbols, such as analyzing events that occur in the dream or deciphering a dream through the Javanese technique of the calculation of days. Using the first method, we can interpret the dream based on the Sunan's actions, such as his smile, his white clothes and the hoe. The smile indicates that Sunan Tembayat was happy with the effort. White clothes signify the pureness, meaning that one has to check the intention of the pursuit. The hoe can be interpreted as a tool for work. Thus, Sunan Tembayat urged the person to pursue the purpose through the hoe, not through the amulet. The second method interprets the dream through the Javanese calculation of the day on which a dream occurs. The Javanese assign certain days certain values, such as Monday $=$ four, Tuesday $=$ three, Wednesday $=$ seven, Thursday $=$ eight, Friday $=\operatorname{six}$, Saturday $=$ nine and Sunday $=$ five. Furthermore, the Javanese also assign certain values to Javanese days, ${ }^{2}$ Wage $=$ four, $K$ liwon $=$ eight, Legi $=$ five, Paing $=$ nine and Pon $=$ seven. Thus, if a dream has occurred on Monday Legi, the dream has a value, $4+5=9$. Because nine is a 'good' value, the dream has a 'good' value too. The second is so complicated, only a few people have mastered it."

To determine if someone has received barakab from SuTembayat is a difficult task because barakah is intangible and is given in a sign (ngalamat) in a dream. Although visitors sometimes obtain ngalamat 
through natural phenomena, such as birds, snakes and so forth, it is difficult to judge if that natural phenomenon is the ngalamat. The coming of a snake or bird for example is not a strange condition in Hastina Agung, which is located on a hill. Since visitors cannot exactly determine the barakah, barakah is always a kind of mystery.

For first-time visitors there is some doubt about the possibility of gaining barakah in the graveyard. Although they ostensibly believe that the personage buried in the graveyard is only sleeping, waiting for the day of judgement, they often have doubt. Can barakah be acquired in the graveyard? A visitor explained his experience:

"Actually I did not want to come to the graveyard, because it is difficult for me to rationalize it. How can I ensure that the ngalamat that occurred in a dream is a sign of barakah; How can I get barakah from the personage? My puzzle is how can we communicate with the Sunan, as we cannot directly meet him?", said a visitor who, until he told me the story, did not know how to interpret ngalamat. I asked him, "But as a Javanese you do not believe that the dead can still communicate with the living, in a dream for example?". "Of course I believe that. However, communications occurring in dreams mostly are related to personal matters, such as the family's neglect of visiting him and so forth. My brother told me that the Sunan gives barakah to visitors with a wide range of problems. It seems that Sunan Tembayat knows everything happening in the real world. Anyway, the puzzle occurred on my first visit, but I feel mantep (faithful, assured), since the juru kunci and the people who have succeeded in their ziarab explained the process of the transmission of barakab."

Juru kunci refer to the value of the day, petungan (the Javanese numerology systems), and the meaning of natural symbols. Javanese believe that an event can be interpreted differently according to the time and day of the event. ${ }^{3}$ For example, death is a common phenomenon. However, if the death occurs on the night of Friday Kliwon, it has a special meaning. I witnessed a death which occurred on a night of Friday Kliwon, and it attracted people from areas all over Java pursuing the kafan (cloth used to wrap the corpse) of the dead. It is believed that the cloth can be used as an amulet, for those who possess the cloth can disappear (menghilang).

In addition, juru kunci interpret the ngalamat of barakab in reference to visitors' successes, meaning that the interpretation is based on the visitors' account of their ziarab success. Juru kunci often name people whom came and gained barakah. These successful people have a major influence on visitors' beliefs. Firstly, when visitors perform a ritual procedure that is similar to the successful visitor's procedure, 
they hope to receive similar ngalamat. The ngalamat, then, is interpreted much as it was by the successful people. Secondly, these people provide 'an example' for other visitors. Finally, these successes have persuaded visitors to continue their ziarah. Juru kunci also use visitors' successes to help them interpret ngalamat.

These two fundamental features of a juru kunci, as the ziarab mediator and as the interpreter of ngalamat, are significant factors involved in determining the failure and success of the ziarah. Consequently, juru kunci influence the ways ziarah rituals are conducted. For example, one juru kunci has a certain procedural ziarab that should be performed by a visitor to gain barakah. The procedure, needing mental readiness, also requires physical endurance. These experiences were recounted by a visitor:

"I have followed a juru kunci's procedure for performing ziarah. I was told by the juru kunci that I should visit Bayat at night, so I could stay at least a night at the graveyard. This is because most of the Sunan Tembayat's ngalamat were given at night. Furthermore, I should stay awake all night long to await (ngadang) the ngalamat, as no one knows when it will be given to visitors. The juru kunci also said that the ngalamat was not given in a clear way, but through symbols. The symbols might be given to visitors in a dream, during meditation or through natural signs, such as snakes and birds. Often an ordinary man has difficulty in interpreting the symbols. However, juru kunci, as they are descendants and the abdi (servants) of the Sunan Tembayat, can interpret the symbols. Moreover, juru kunci also know the causes of visitors' failures to obtain barakab from the Sunan. Therefore, I follow the juru kunci's instructions and suggestions to complete the procedure of ziarah."

For visitors, juru kunci are not only the custodians of the graveyard, but are also sources for consulting on ziarah success. Juru kunci provide an analysis of the ziarah success by interpreting ngalamat and explaining how to fulfil the requirements needed to manifest it. Juru kunci are also important figures for consultation of what should be done after receiving the ngalamat.

Juru kunci interpret the ngalamat that are given through natural phenomena. The ngalamat granted in natural phenomena only occurs rarely, and it is difficult to determine whether certain natural phenomena are as ngalamat. However, if a natural ngalamat is received by visitors in a special way, it is easy to interpret it. The juru kunci explained:

"A man came to me asking to interpret the ngalamat he gained. He said that a snake came to him while he was meditating in the area close to the main 
building of Sunan Tembayat's tomb. As a normal person, not as a Juru kunci, I feel that a snake is a dangerous animal. It is a normal circumstance that in the hill area snakes appear. However, in the sacred place, everything embodies a meaning. In Javanese belief a snake is a symbol of power. I, then, interpret the snake as a ngalamat of the coming of power, profane or sacred, for him. Profane power could be manifest in a status position, and sacred power could be characterized by the coming of pusaka or kesakten (inner power). Two years later, the man again visited this tomb and said to me that after receiving ngalamat of a snake, he won election as Lurab (village chief). When he conducted a hajat slametan, he reminded me about the snake coming during his meditation."

Juru kunci are regarded as having spiritual power which derives from Sunan Tembayat. Juru kunci are kesawaban (influenced spiritually) by the Sunan Tembayat's barakah. In this privileged position, the juru kunci become the main focus for conducting and interpret-
ing ziarah.

\section{Juru kunci and the Transmission of Barakab}

Juru kunci are the Sunan Tembayat's abdi. Abdi is a Javanese word denoting 'a giving of total dedication and obedience'. As abdi, juru kunci are people who are supposed to be totally dedicated to their work and effort in serving (mengabdi) Sunan Tembayat. juru kunci serve Sunan Tembayat as a king, a pundhen (ancestor) and as a religious teacher. Therefore, juru kunci, as Sunan Tembayat's abdi, act as the mediators, servants, officers, guardians and interpreters of Sunan Tembayat. This implies that, in the hierarchy of ziarab ritual, juru kunci are the closest people to Sunan Tembayat.

As the abdi of Sunan Tembayat, juru kunci always gain barakah from Sunan Tembayat, although they do not physically perform ziarah. They obtain barakab from Sunan Tembayat in a different way. Unlike visitors who obtain barakah through performing ziarah, juru kunci acquire barakah through a special process, called kesawaban, meaning 'influenced spiritually'; for example, like the wife of a president who is kesawaban due to her husband's position, becoming First Lady. Through kesawaban juru kunci claim eternal barakah.

Kesawaban is also used by Paseban dukub (hamlet) people. They argue that Paseban people receive barakah because they are part of Bayat's community, which is genealogically linked to Sunan Tembayat. The sawab, the word they usually use to denote the barakah's impact, can be seen from their access to developmand economic opportunities. The market that sells flowers, incense and other 
ziarah equipment produces job opportunities for Bayat people and those in surrounding areas. Their special skills in pottery skill are promoted to visitors, Bayat's pottery, for example, is known by Klaten people as being of the best quality. The Indonesian government has facilitated tourism in Bayat by providing services such as good roads. These infrastructure developments also mobilize Bayat's people.

The positions of juru kunci as the mediators and interpreters of Sunan Tembayat's message are strengthened by the Javanese beliefs about pasarean and sare. In referring to the graveyard, Javanese people use the word kuburan or pasarean and/or makam. The word kuburan derives from kubur meaning 'to bury', kuburan as a noun thus denotes the place for burying. The term makam derives from Arabic, meaning a 'graveyard'. Pasarean, on the other hand, is a noun framed from sare, meaning to sleep. Thus pasarean signifies a place for sleeping. When Juru kunci and visitors allude to Sunan Tembayat, they do not say that Sunan Tembayat has passed away; rather they say that Sunan Tembayat is sleeping (sumare from sare).

This leads to the important question, on what the relationship between juru kunci and Sunan Tembayat is built on. There are three contributing factors to the juru kuncis' special position before the saint. First, some juru kunci base their special status on a hereditary basis. It is true in Bayat that some juru kunci have a direct genealogical link with the Sunan. Second, they are custodians of the Sunan Tembayat's place. Therefore, juru kunci are kesawaban by the Sunan Tembayat's spiritual power. Third, they are regarded as people who can interpret the ngalamat given by Sunan Tembayat through dreams. These factors enable juru kunci to act as special mediators between visitors and Sunan Tembayat. Juru kunci establish their special function as the "tanganipun kanjeng Sunan" (the Sunan Tembayat's hand). 'Hand' has several meanings including that of assistants, speaker, mediator and acting power for the Sunan. In addition, some juru kunci also claim their special position before the Sunan Tembayat was revealed in a dream. Some say that before they became juru kunci, they asked Sunan Tembayat's permission by performing ziarah. Sunan Tembayat revealed his permission through ngalamat in a dream. In a dream, for example, Sunan Tembayat may ask the person to accompany him to the market. The Sunan's request is seen as a ngalamat giving his permission.

In many cultures dreams have several important functions, as a source of inspiration or a tool for legitimacy. In Islam, for example, a 
dream is one of the many ways used by God to reveal commandments. The Prophet Abraham received in a dream a revelation from God to slaughter his son. The Prophet Yosef was informed of his next duty through a dream. God also gave the Prophet Yosef knowledge to interpret dreams. He interpreted the King of Egypt's dream, which became a reality. The Javanese regard dreams as a kembange turu' (the flower of sleep) or 'wangsit or ngalamat' (a sign or revelation). A dream can be seen as kembange turu if it occurs before the middle of the day. This kind of dream cannot be used as ngalamat. However, if the dream happens in the middle of the night or during early morning, it contains a message. ${ }^{4}$ Mostly, the message in a dream is manifest as a symbol that should be interpreted. For example, if a person dreams that his teeth are extracted, it means that a relative will die. Furthermore, dreams are also used to ask for specific revelations. A famous kyai from Tegalrejo in Magelang, before building a Pesantren, slept at his teacher's tomb asking his blessing (Pranowo, 1991).

Descent is also an important factor in legitimacy in Java. It is believed that some knowledge, such as of leadership and inner knowledge (ilmu batin), is transmitted through genealogical lines. This wellknown concept is used in the Sufi tradition. ${ }^{5}$ Javanese believe that power, knowledge and the potency to become a good person can be inherited as can the power to select a girl or man to marry. The concepts of bobot (quality, especially wealth), bibit (descent) and bebet (knowledge and good behavior) are used to select candidates. By acknowledging themselves as the descendants of Sunan Tembayat, juru kunci establish their identity and the legitimacy of their knowledge and quality.

For visitors, juru kunci sometimes have a more important significance than the Sunan himself in ziarah, because visitors can communicate and hold dialogue only with the juru kunci. They respect the juru kunci just as they respect Sunan Tembayat. Although in normal circumstance visitors have higher status than juru kunci, in the process of ziarab visitors treat juru kunci as well as they would treat Sunan Tembayat. As the interpreter of ngalamat, juru kunci are regarded by visitors as the most significant people in their ziarah. Without a juru kunci's assistance in interpreting ngalamat, visitors cannot decide whether their ziarah was successful or not.

Juru kunci translate the ngalamat to decide about barakah. In cases when visitors fail to receive ngalamat in their dreams, juru kunci also 
analyze the factors involved, and provide diagnoses to solve the problem. Therefore, one visitor said of the Juru kunci, "juru kunci are like a radio, which receives a broadcast. The interpretation of Juru kunci, truly, is similar to a radio broadcast that we hear" (juru kunci niku kados radio ingkang nampi suanten sangking pemancar. Penjelasane juru kunci menika, sak jatosipun, inggih kados suanten radio ingkang saget kita merengaken). The mediator is an agent who acts on behalf of someone and as a vessel for the Sunan.

Visitors can choose a juru kunci to assist them. For visitors who visit Sunan Tembayat on a regular basis, they know the juru kunci's ways of assisting in ziarab ritual. A visitor told me that he had been assisted by all juru kunci, but only one juru kunci provides him with satisfactory assistance. He further describes the factors involved in the selection of juru kunci. First, the juru kunci's ways of ziarab is coincided with the visitors' hopes. Second, the juru kunci has enabled the visitor to gain barakah. Third the juru kunci interpreted the dream correctly. He said:

"While I was meditating, a bird came to me. Although the bird was not so close to me, it stared at me. I told this matter to one juru kunci and he said that it was an ordinary bird, which had no connection with my meditation. I was not satisfied with this explanation, and I went to another juru kunci. He interpreted the bird as a guest. He further said that I would have an important guest who would help me to improve my life. The second interpretation was true, because ten days later I had an important guest who established a business relation with me. Since then, I have always asked the juru kunci to accompany me in my ziarah."

Therefore, a juru kunci and visitors establish a special relationship in performing ziarah and interpreting it. The juru kunci's way of ziarah is affected by visitors' wishes to obtain a certain barakah. Some visitors, especially those who come from outside Klaten have spent a lot of money to visit Sunan Tembayat's tomb. It is understandable if they want to be assisted by a juru kunci who is familiar to them. On the juru kunci's side, juru kunci need to maintain the relationship with visitors. The juru kunci will assist in accord with visitors' wishes and in return obtain a tip from them.

To sum up, the juru kunci play a significant role in determining the transmission of barakah, since they are regarded as having authority to interpret the ngalamat. Through their role in interpreting ngalamat, juru kunci can ascertain visitors whether have received barakab or not. Sometimes the ngalamat of barakab is not clear, and 
visitors do not know the meaning of the ngalamat. Therefore, juru kunci's interpretation of ngalamat provides affirmation of the ziarah success.

The juru kuncis' dominant role in interpreting ngalamat enhances the individual relationship betweenjuru kunci and visitors. In interpreting ngalamat the juru kunci interpret the meaning of ngalamat according to the visitors' wishes. Furthermore, juru kunci and visitors often create a certain ziarah procedure, which is believed as the appropriate method to achieve certain ziarah's goals. Therefore, visitors select juru kunci who can accommodate their aims to ascertain the success of their ziarah. On the juru kuncis' side, the relation is maintained to sustain their popularity. Since visitors visit Sunan Tembayat's tomb with diverse intentions, juru kunci interpret ziarah in various ways.

\section{Sacred and Profane Domain}

To gain an understanding of the concept of sacredness associated with Bayat it is essential to appreciate that visitors in Bayat respect the graveyard and its surrounding area because they regard them as being in some manner emblems or representations of the existence of Sunan Tembayat's sacredness. As the sacredness of Sunan Tembayat is only known in and through objects such as the graveyard, the tomb, the padasan, and the cloth, the sacredness can never be wholly dissociated from these objects. Therefore, those who respect an object or a person say that it is Sunan Tembayat himself, and not the object, that they call on for aid; it is to him that they dedicate their donga (prayer) to. Thus, I was told by a man who venerates Sunan Tembayat's padasan (a jar to store water), that "the padasan is only a symbol of Sunan Tembayat's barakab" (padasan niku lak namung perlambang berkahipun Sunan Tembayat). This means that not the padasan itself is barakah, but the fact the padasan was used by Sunan Tembayat that padasan contains barakah.

The words used to indicate this special attention to the sacred objects, which I have translated as 'respect' and 'to respect', are hormat and bekti. The term hormat implies 'respect' due on account of a person's superiority, whereas bekti signifies showing respect through complete obedience. Visitors express hormat and bekti to Sunan Tembayat through formal acts such as deferential walking in front of his tomb, refraining from causing damage to the site, giving flowers, burning incense and so forth. The respect is reciprocal; visitors who 
respect or help Sunan Tembayat in turn expect to be helped and respected by Sunan Tembayat. One general characteristic of the distinction between sacred and profane objects is that sacred objects contain power derived from supernatural beings. The power also can be attached to objects that have relationship with supernatural beings. For example, in the Hastina Agung graveyard, certain objects are considered to be sacred and to have power as they are connected with the personage of Sunan Tembayat who was considered to have spiritual power. The padasan (a water jar) is considered sacred because it is believed that the padasan was used by Sunan Tembayat for his ablutions. Thus, the padasan and its water are sacred, containing barakah from Sunan Tembayat.

Furthermore, visitors and juru kunci regard things as sacred or profane depending on the function of the object. For example, when juru kunci assist in ziarab rituals, such as the jawab ritual, they are regarded as sacred. Visitors give respect to juru kunci and obey their commands with complete dedication. Disregarding such commands, visitors believe, could cause misfortune and threaten their chances of acquiring barakah. However, in everyday life, juru kunci are treated as ordinary people. Incense is also treated differently in different contexts. As a requirement of ziarah, incense burned during the jawab ritual and meditation is described as sacred. Nevertheless, in the market, incense is only a commodity and does not command special respect.

Visitors also display respect for certain places. Hastina Agung graveyard can be divided into three areas; the outside area (wilayah jaba), the inside areas (wilayah jero) and the core area (wilayah inti). These places are considered sacred because they are related to Sunan Tembayat. All places used to protect and to show hormat and bekti to Sunan Tembayat are considered sacred. An interpretation of the association between the place and Sunan Tembayat is not to be sought in the nature of the objects themselves but in an association that provides meaning to them. Similarly some visitors respect Ki Ageng Pawilangan (Sunan Tembayat's secretary) and ask him numbers for the SDSB (a kind of lottery game), precisely because he was Sunan Tembayat's secretary. In this regard, visitors look to the relationship with Sunan Tembayat. It seems, thus, visitors respect various personages because they have a link with Sunan Tembayat.

The outer area of the graveyard covers the area between the gapura panemut and the gapura prabayeksa, the area of the graveyard of Sunan 
Tembayat's descendants. The inner area extends from the gapura prabayeksa to the main building of Sunan Tembayat's tomb. The core area (inti) is the area inside the main building of Sunan Tembayat's tomb. The outer area is considered the profane domain, where visitors can behave normally, without special requirements. However, in the inner area and in the core area, which are considered sacred, visitors must behave respectfully. In front of the gate, there are certain requirements for visitors. These include removing their shoes and refraining from any sexual involvement. Ignoring these requirements will cause harm or misfortune. The main area of the graveyard is regarded as the most sacred place, and here people behave respectfully, avoiding improper words and improper intentions.

However, the classification of sacred and profane domains in Hastina Agung is debated. Some visitors regard the entire graveyard area, without exception, starting from the first gapura panemut to be sacred. According to this view, when visitors enter the big complex of Sunan Tembayat's graveyard, they have entered the sacred place. According to these visitors, the ngalamat of Sunan Tembayat can be gained anywhere in the large complex. For example, the number of stages or the ability to climb the stages involves ngalamat. It is believed that an old person with limited energy might climb easily if he/she gains barakah, while a young man might find it hard to climb the stages if he fails to gain barakab. For these visitors the preparation for the ziarah ritual, such as taking ablutions, changing clothes and preparing flowers and incense should begin from the first gapura.

The respect given to a certain place depends on whether it is regarded as sacred or profane. For those who believe the sacred place begins from the mosque area at the top steps, preparations for the ziarah ritual begin at that point. For these visitors, the steps are not regarded as sacred, and so they do not give them respect. There are also some people who argue that all areas of Sunan Tembayat's complex are profane, except the main area of Sunan Tembayat's tomb. These people pay respect only to Sunan Tembayat's tomb.

Another example of the different perceptions of what is sacred or profane occurred in the pasang singep ceremony. There was a debate about what was sacred about Sunan Tembayat's heirloom (pusaka), contained in an empty box. It is believed that the box, located at the right side of Sunan Tembayat's tomb, is the place for Sunan Tembayat's heirloom. In other words, the box itself is not the heirloom but what is in it. Some juru kunci, relying on traditions, put a 
baby's blanket (kemul bayi) in the box to represent the existence of Sunan Tembayat's heirloom. These people argue that the use of the baby's blanket is to symbolize the purity and the sacredness of Sunan Tembayat's heirloom. Because the blanket and its box represent Sunan Tembayat's heirloom, visitors regard them as sacred. Therefore, these visitors give respect to the box as well as the blanket.

However, other juru kunci argue that the sacredness of Sunan Tembayat's heirloom is not the box, the baby's blanket or anything else, but in the belief in the heirloom's existence. All juru kunci agree that Sunan Tembayat's heirloom has no real physical existence. It implies also that the heirloom cannot be symbolized anything, not even a baby's blanket. The box contains nothing. The nothingness represents the power of the heirloom which cannot be symbolized by any physical existence. Nevertheless, what is in the box, which has no material existence, is regarded as sacred. People can move the box, but they cannot move the heirloom. They can break the box, but they cannot break the heirloom. If the heirloom was represented by a material object such as a blanket, then that object could be mistaken for the heirloom.

In determining the sacredness of certain objects visitors see the context of the object. Without having a detailed knowledge of the cultural background that provides the context for the concept, no explanation of sacredness can be achieved. The way in which visitors categorize the graveyard areas into sacred and profane domains is related to this cultural context. Sacredness depends on the context in which objects are perceived. Visitors believe that water stored in the padasan is water which does not differ from other water. Moreover, visitors also know that water in the padasan is ordinary water brought by juru kunci from the village well; it does not come from Sunan Tembayat. However, people believe that since the water is stored in Sunan Tembayat's padasan, which is considered as sacred, the water has a different function and power. Similarly, sleep is a normal activity of human beings. However, sleep in Sunan Tembayat's graveyard has a different meaning. It is normal for people to dream, but a dream that occurs in Bayat has a different meaning. The context and place imply different meanings for the dream.

In addition, the sacredness of an object is not necessarily permanent. In so far as an object has no relation to a sacred entity, and has not been endowed with sacred power, the object is not sacred. However, when an object is related to a sacred entity, the status of the 
object changes. A juru kunci explained:

"A kris [dagger], before it is bestowed with a power by the Empu [literally the master of a certain skill, such as making poems or kris], is ordinary metal. However, when it has been given power, the kris has a different status. A smith can shape and forge the kris, but if he was asked to forge the kris Nagasasra, he would not dare to do it. It is also the case for Sunan Tembayat's tomb. Before the tomb was used to bury Sunan Tembayat, it was carved by the stone master. However, if you ask him to carve Sunan Tembayat's tomb now, he would not want to do it. The power of the kris can be installed and, therefore, it also can be cleaned. When the kris loses its power, it returns to its original state. Therefore, the sacredness of Sunan Tembayat's tomb also can be cleaned; through the niat (intention). This means that when we want to clean the tomb, we ask permission of Sunan Tembayat, and we declare that the intention of our work is not aimed at disturbing Sunan Tembayat, but at cleaning the place to make it more comfortable for Sunan Tembayat's rest."

Objects that are considered as sacred in Bayat have some connection with Sunan Tembayat. The graveyard is sacred because it is Sunan Tembayat's pasarean; the tomb is sacred because it is his tomb; a snake in the graveyard is considered sacred, because it is in Sunan Tembayat's graveyard; the padasan and its water are sacred because it is Sunan Tembayat's padasan. There are other padasan, but they are not considered sacred. People in Bayat do not consider the sacredness of an object to be determined by the object itself. Furthermore, the sacred quality of an object is a kind of entity which can be installed or removed. The sacredness of an object is not inherent in the object itself, but it only resides in the object for a certain time. In this case, the tomb itself is not sacred, but the power which resides in the tomb is sacred. Whenever the sacredness is removed from the object, the sacredness of the object also disappears.

\section{Incense, Flowers, Water and Berkat}

Edmund Leach argued that the redundancy in ritual performance is aimed to emphasize the meaning and goals of ritual forms. Leach explained the repetitiveness of ritual behavior in terms of communication theory. Humans ensure that their message has been understood, by repeating it in the same forms, and expressing it in a visual form. Ritual, as a means of communication, he pointed out, contains condensed symbols of relevant cultural knowledge. In other words, ritual is a way of transmitting information through symbols portrayed in its performance. In Leach's view, ritual has affinities with 'com- 
puter programs' (Leach, 1979:230-231). Redundancy in ritual performance is to reinforce and emphasize a message; to stress the significance of the message.

Symbols in ziarah rituals can be understood from such a perspective. In their ziarab rituals, visitors to Bayat prepare incense, flowers, and sometimes they also make sesaji (homage). Juru kunci argue that all things are symbols containing messages for people to follow. However, Leach did not explain that the meaning and significance of symbols can change or can be interpreted differently by participants. I argue that symbols used in ziarab rituals are interpreted in different ways and are sometimes given new meanings. The interpretation of symbols used in ziarab demonstrates that the meanings of symbols are interpreted differently by different participants.

\section{Incense}

Incense has had a religious significance throughout history from ancient times to the present day. Incense is used in ritual offerings to the gods or in the worship of gods. Incense has been described as 'the food of gods' and the perfume of gods (Groom, 1981:1). It is also true in Java, especially in connection with visiting tombs that incense, at least for some visitors, has something to do with God. Visitors bring incense and flowers as a requirement for completing their performance of ziarah. However, their explanations for using incense and their interpretations of its meanings and functions in the ziarab tradition, vary.

The Javanese word used to refer to incense is menyan (kemenyan, or dupa). Javanese use incense mainly in activities concerning supernatural powers, in rituals, in the maintenance of pusaka (heirlooms), in conducting sesaji (paying homage) to the spirits and so forth. For example, incense is burned close to the sacred pusaka of Yogyakarta's court. In the Garebeg ceremonies the sacred pusaka are paraded before the public. ${ }^{6}$ On this occasion, incense is burned to tame the wildness of the pusaka and to pay respect to the pusaka (Soelarto, 1993:7884). Javanese people who practice meditation burn incense to sharpen their concentration.

Like the debate about the ziarah ritual, the debate about the use of incense is also crucial. This is because the history of the use of incense in Bayat society has many explanations. First, some visitors say that the function of incense is to invite a spirit. An informant described his experience in invoking a spirit in his childhood. 
"On the night of Friday Kliwon, after we recited Barzanji (the history of the Prophet Muhammad) in the langgar (a small mosque), the teenage boys played a Jaelangkungan. They made Jaelangkung like a human (orang-orangan) made from wood. Two pieces of wood tied up like a cross-wrapped in clothes to represent the body. The coconut shell (batok) is painted with eyes, nose and mouth to represent the head. Then, one of us acted as dalang (puppeteer), to move the Jaelangkung, like a wayang (a leather puppet). We burned incense and recited donga, invoking the spirit. After a while, the person holding the Jaelangkung went into a trance, which indicates that the spirit has entered the Jaelangkung. We asked the Jaelangkung questions about our secrets, the number for buntut (a kind of lottery game) and so on. The dalang's answers are believed to be the spirit's voice. I thought, like my friends, that incense was a means of calling a spirit. When we were satisfied we extinguished the incense and bathed the person with water."

Other visitors and juru kunci, however, argued that incense is only a means of making a place aromatic. Furthermore, the incegets rid of insects, e.g. spiders and mosquitoes. Traditionally, before mosquito repellent was available, people in rural villages used smoke to get rid of mosquitoes. ${ }^{7}$

Other visitors suggested that incense is symbolic. The spread of the smoke and fragrance of incense and visible movement of that smoke upwards towards the heavens gives it a symbolic relationship to prayer, making the offering synonymous with the worship of God who, they believe, exists above. In Bayat this symbolism can be seen clearly in the use of tobongan in the jawab ritual. This symbolism encourages people to direct their prayers and hopes toward God, not toward the tomb itself. Furthermore, the visible upward movement of smoke reminds people where they should address their prayers.

\section{Flowers}

Flowers are also used in ziarah traditions. Visitors regard the use of flowers in ziarah rituals as a requirement and as a sign of barakah. While the incense is burned in the jawab ritual, the flowers are scattered over the tomb in ziarah. After completing ziarah, visitors repossess the flowers which have been scattered on Sunan Tembayat's tomb, because they believe that the flowers have been blessed by Sunan Tembayat, and now contain barakab. Women put the flowers in their hair (gelungan from gulung, meaning to fold), or at their breast, whereas men put the flowers in their pocket or in their hats (iket or peci).

According to visitors, every ziarah place requires different flow- 
ers. For example, kembang telon (a combination of three kinds flowers) is suitable $(c o c o k)^{8}$ for ziarab in Bayat, whereas other places may require other kinds of flowers. An informant who had visited all the Javanese wali said that every place of ziarah requires a specific kind of flower. If visitors bring the wrong flowers, it will affect the success of their ziarah. Therefore, he always asked visitors or the juru kunci to tell him what flowers should be used. For this visitor, flowers are a requirement of ziarah, and function to determine the success of the ziarab.

However, other visitors interpret the function of flowers in ziarah rituals differently. Some visitors argue that flowers function like incense, implying that flowers are also the food of gods. The aroma of the flowers is used to persuade gods to hear their requests. Some visitors point out that the function of flowers, like that of incense, is simply to make the area fragrant and pleasant.

Juru kunci argue that the flowers are symbols which contain messages for visitors. Flowers symbolize beauty and goodness. Therefore, the flowers suggest good deeds and good behavior, functioning to create inner beauty and goodness in visitors. However, when the aroma of flowers has gone, they will be useless. Juru kunci cite the analogy that if a man has nothing worth taking from him, he is useless.

Water

During ziarah ritual, people use water before entering the graveyard or at the beginning of the ziarah, and after the ziarah. The padasan in front of the mosque in Sunan Tembayat's graveyard or the padasan at the langgar at the first gate of the graveyard are prepared for visitors' ablutions. The ablutions signify the visitors' intention to cleanse away their sins; they also symbolize the purity of visitors' ziarah intentions. Furthermore, visitors make ablutions to protect themselves from the influence of bad spirits. It is believed that a bad spirit can enter a person's mind, and the ablutions are a means of protection from this. In short, the ablutions are conducted to show the eagerness of visitors to obtain barakah.

In front of the main building of Sunan Tembayat's tomb, there are two padasan storing water. Glasses and siwur (a ladle made from a coconut shell) are also provided. Here, water is used to symbolize Sunan Tembayat's barakah. Some visitors drink the water after completing ziarah, whereas others take the water home. It is believed that 
the water stored in the padasan is an expression of Sunan Tembayat's barakab. Like the flowers that are taken home by visitors, the water is also consumed for good fortune, and as a cure for disease.

The water is also believed to symbolize coolness, harmony and cleanness. Water cools anger, as water resists fire. A person who feels thirsty, drinks water, just as plants and the earth consume rain. Thus barakah, like water, functions to cool and refresh people. If someone feels angry or thirsty, he/ she should consume barakah from the saint. Moreover, just as water permeates the body, barakah should permeate the body.

\section{Berkat}

Berkat derives from the Arabic word barakah; it is Javanized as berkat or berkah. ${ }^{9}$ All these words are interchangeably used by Javanese. There is of course a connection between them. The word berkah is used to refer to a portion of rice or food obtained from something perceived as having supernatural power. For example, a santri (a student of a pesantren) regards the left overs from his kyai as containing berkah. In the Surakarta court the dung of kyai Slamet, a white buffalo, is considered to have berkab. Furthermore, in the Yogyakarta court, people compete to acquire the water used to wash the court pusaka, since it is believed that the water contains the pusaka's power. The water is also called berkab/t.

The Javanese term berkat has yet another sense; it is used to refer to a portion of rice obtained in a slametan ceremonies. For example, in slametan to celebrate the birth of a child, participants return home with rice or food. The portion of food is called berkat. In the Garebeg ceremony in Yogyakarta court, people take some rice from the gunungan (rice shaped into mountain), and this is also called berkat because it contains barakah (Soelarto, 1993:57-66). Just as the rice obtained in a garebeg ceremony carries barakah from the king, the berkat gained in the slametan in Bayat contains barakah from Sunan Tembayat. People in Bayat also use berkat to refer to the payment for modin (religious officers) for their services of offering prayers.

Why is an object itself referred to as berkat or berkab? Different people offer different explanations. First, it may be designated berkah because it has a relation with a special person or object. People use the dung of kyai Slamet, because it is the dung of a special creature. In some traditional pesantren, santri strive to acquire their kyai's left overs (turahan), such as his drinks, meals, and cigarette. 
Second, it is believed that the power of certain powerful creatures will transfer to things they touch. The water used to wash the court pusakas, thus, also contains power. Therefore, people consume the water to share its power. Similarly, a portion of rice obtained from a slametan held in the Bayat graveyard also embodies barakab from Sunan Tembayat. For some visitors who have been staying at the graveyard for more than a day or even a month, the berkat of slametan is regarded to be a part of Sunan Tembayat's barakah. These visitors say that the rice from a slametan is a berkat from Sunan Tembayat in a material form. Others, however, do not eat the berkat, because they feel it too valuable (sayang) to eat. These visitors believe that the berkat is better as fertilizer for their crops or as medicine for their cattle, rather than to be consumed as food.

Visitors conduct slametan for two reasons, first as an expression of thankfulness to Sunan Tembayat, and second as a sign of willingness to receive barakah from Sunan Tembayat. The first slametan is performed after visitors have received barakah, claiming that their goals have been achieved, whereas the second slametan is conducted before performing ziarah. This slametan is aimed to declare the bajat (purpose) of the ziarah. Therefore, this second slametan is called hajat.

Hajat slametan are different from other slametan. Hajat slametan are larger in size and more complete in their requirements than other slametan. Juru kunci say that the hajat slametan should have two kinds of rice, sego golong (rice shaped into a ball), and sego $u d u k$ (rice cooked in coconut milk, so the taste is gurib=savery). The rice is placed on the tampah (a round plate made from woven bamboo) with gudangan (coflavored, mixed vegetables), and ingkung (a whole, boiled chicken). On top of the gudangan, there are some jenang (sweat rice cereal) called jenang pura in two colors, abang (red) and putib (white). According to the juru kunci these foods evoke messages. Sego golong symbolizes closeness to family. Golong means 'group', and sego golong means that the family members should share their wealth and riches. Sego uduk teaches people to enjoy the meal, although it is only with coconut flavored vegetables. The mixed vegetables signify that people should interact with other people. Jenang abang and jenang putih, which together are called jenang pura (forgiveness), signify respectively the dirtiness and purity of the body. Therefore, people should ask for ngapura (forgiveness from the community and from God). Ingkung symbolizes pasrah (acceptance without complaining). Visitors should accept any barakah that is given to them, as the best for them. 
Syukuran slametan to express thankfulness to God is conducted in a larger and more complete size than hajat slametan. The content of the slametan is the same. However, the syukuran slametan also involves fruit; and the portions of rice and vegetables are bigger in size than those provided in hajat slametan. The slametan convey messages that people who have gained their goals should share their wealth and pleasure with other people. The use of fruit signifies the successful result (buab), and a feeling of freshness and happiness after receiving barakah from God.

It seems that the ziarab ritual is a means of teaching people by using symbols. It has been argued that the importance of ziarab is not in visiting the tomb, but rather in how people grasp the meanings and messages of ziarab traditions. The use of symbols is intended to condense these messages, so that people can appreciate them. However, since the meaning of symbols used in ziarah is varied, people interpret the symbols differently. Interpretation of incense, flowers, water and berkat of slametan can vary.

\section{Donga-Donga (Prayers)}

Visitors recite donga at the slametan, at the jawab ritual and at ziarab performances in front of Sunan Tembayat's tomb. Visitors usually ask juru kunci to recite donga in slametan and in the jawab ritual, whereas visitors recite their own donga at Sunan Tembayat's tomb. Juru kunci recite donga in slametan using both Javanese and Arabic. The Javanese donga is recited to state the visitors' requests to Sunan Tembayat along with asking permission and forgiveness, while the Arabic donga is recited at the end. At the tomb itself, most people recite donga silently because these are regarded as secret. However, some people recite donga loudly, using tablîl donga. Although at jawab rituals and slametan ceremonies it is usually the juru kunci who recite the donga, everyone has the right to formulate their own donga, to state any requests, and to use any language.

People frequently discuss the language used in reciting donga. Some suggest that it is better to recite donga in Arabic because God will pay more attention to people who recite donga in Arabic. Other visitors argue that the donga should be recited in a language that people know, so that people know exactly what is said in the donga. Still others do not agree with either of these two groups, which only focus on the formal language of donga. The third group says that the most important part of the donga is the content itself, not the language. People 
can use any language they want, even if they just recite donga silently in the heart. God knows all language spoken in this universe. The donga can be recited in mixed languages, Javanese and Arabic.

Most visitors use both Javanese and Arabic donga. According to visitors and juru kunci the use of Arabic donga and Javanese donga in ziarah performances is related to the concept of mantep (completeness, fulfillment, satisfaction, confidence, determination). Different languages should be used depending on whom the donga is directed. The Javanese donga is better used to address Sunan Tembayat, because, people argue, Sunan Tembayat was Javanese; he communicated in Javanese language. Therefore, if people want to communicate with him, it is better to use the language recognized by him. On the other hand, Arabic donga are recited when they are directed to Allah. This, people argue, does not mean that God speaks in Arabic. God belongs to all humans. He can communicate in any language. Arabic is used because it is afdol (Arabic, meaning 'better', and 'more perfect') for donga recited for Allah.

The general pattern of the donga in the slametan and jawab rituals has three components. First, visitors state the purpose of their ziarah and introduce themselves giving their name, origin and so forth. Second, the juru kunci pass on the message to Sunan Tembayat, and the third step is reciting the donga. Sometimes, however, procedures of reciting donga in slametan, hajat and syukuran, differ from the procedures in jawab rituals. For example, in the latter people might state the purpose and intention of their ziarab to juru kunci and ask them to recite the donga. Juru kunci ask visitors what language they prefer for their donga. Most visitors request both, that is Arabic and Javanese donga. Juru kunci recite donga in accordance with visitors' requests.

Hajat slametan and syukuran slametan, which are held at the bangsal juru kunci (the hall of juru kunci), begin with the declaration of the intention and purpose of the slametan and its ziarah. Visitors then approach the juru kunci and say: "My name is Ngadimin. I come from Semarang. I conduct this slametan to come close to Sunan Tembayat, hoping that he might help me to enlighten and overcome my life problems. I ask the juru kunci to recite a donga that is suitable for my request" (Smelah Hirabmanirohem [originally Bismillâhi Arrahmâni Arrahîm]. Nami kula Ngadimin, saking Semarang. Kula ngedamel slametan punika inggib kula maksudkaken kangge ndepe-ndepe dumateng Sunan Tembayat, mugi-mugipanjenenganipun Kanjeng Sunan 
kersa ambiantu ngringanaken cobaan sarta aweratipun lampab kula. Inggib matur dumateng juru kunci kula sumanggaaken dene donga menapa ingkang cocok lan pas kangge panyurwunan kula).

The juru kunci then recites a donga to Sunan Tembayat and Allah. The first donga is recited in Javanese, while the second is recited in Arabic. Juru kunci argue that reciting the two donga shows visitors the best way to recite donga. The first donga is addressed to Sunan Tembayat, asking for help in mediating with God, and the second donga is directed to God. The use of Javanese in the first donga signifies the influence of Javanese traditions in ziarah, while the use of Arabic in the second donga indicates the Islamic aspect of ziarah. Visitors, who do not understand Arabic, can learn the meaning of the donga through the Javanese version, even though the Javanese donga is not always a direct translation of the Arabic donga. The Arabic donga is a standard donga which is recited in most circumstances.

In summary, ziarah rituals contain symbols that convey meanings. To understand these meanings, people interpret them according to their everyday experience. The interpretations of symbols change, as people's experience of everyday life also alters. Symbols are interpreted according to one's background and knowledge. $\mathrm{Al}$ though it is true that there is a popular interpretation of ziarah ritual symbols, visitors often expand on these, and add their own interpretations. Visitors' different interpretations of ziarab ritual symbols in Bayat show the richness of meanings conveyed in these symbols.

\section{The Concept of Barakab}

The key to understanding the ideology of the transmission of barakah in ziarah rituals is related to the visitors" cultural perceptions of the relationships between wali and God, and visitors' relationships with wali and God. One way of understanding the significance of such a concept is in its connection to social contexts. Considering the conception of barakah without considering the context in which the concept emerges will result in only a partial understanding. It is understandable that meaninand concepts of barakah may vary over time, as the understandings of barakab depend on social and cultural contexts that continually change. Visitors to Bayat in order to provide rationales for ziarah rituals conceive barakah in accordance with their everyday life experience.

Barakah literally means 'blessing, grace bestowed by God', ${ }^{10}$ but 
in Bayat, barakab includes a range of 'mundane qualities': prosperity, abundance, well-being, or merely sufficiency. ${ }^{11}$ Therefore, a farmer articulates Sunan Tembayat's barakah as a fertilizer of crops; a trader interprets Sunan Tembayat's barakah as a means of making business successful; a student conceives Sunan Tembayat's barakah as a way of achieving success in his/her studies. However, some visitors articulate barakah more in terms of 'transcendental qualities'. They argue that barakab consists of a range of sacred qualities, such as luck (untung, beja), reward from God (pahala, ganjaran) and spiritual power (kadigdayan). Similarly, juru kunci assert that barakah is "the same as a reward from God" (barakah niku sami kaleh ganjaran utawi pabala saking Gusti Allab).

A leading kyai of Bayat, ${ }^{12}$ attempts to bridge these interpretations by saying that barakah is a reward from God, which will be given on the day of judgement as well as in this worldly life. On the day of judgment, reward of doing ziarah is expressed in the same value as the reward (pabala) for doing good deeds (ibadab), ${ }^{13}$ while barakah achieved during worldly life is manifest in the prosperity and success in a visitors' daily life, e.g. in farming, trading, employment and so forth. For the kyai, prayers recited during ziarab rituals should address both goals; that is; asking for barakah during this worldly life and on the day of judgement. Therefore, visitors should reserve some barakab achieved during this worldly life to use in performing good deeds (amal ibadab), which will earn them pabala for the day of judgement.

However, some visitors argue that barakah ought to be understood as a process of gaining peace (ketentreman) and wisdom (waskita). People perform ziarah to Sunan Tembayat's tomb because they have problems. Performing ziarab is expected to produce feelings of 'sumeleb' (a feeling of acceptance). Behind the notion of sumeleh lies an acceptance that God has a predetermined plan that is best for everybody. The notion of sumeleb also implies that people should think positively about life; that people should believe that God gives a burden to a person because God knows that the person is able to overcome it. Finally, sumeleh suggests that God never intends to give something bad. Wisdom, in contrast, is to have a clear and full understanding of life's events. In ziarah, people are urged to meditate (merenung) so they can see clearly the symptoms and causes of their actions. Therefore, they can learn from their past (ambil bikmah). A visitor explained to me: 
"Whenever I face a problem, I perform ziarah to Sunan Tembayat's tomb. My first reason is that in Sunan Tembayat's graveyard I can maximize my concentration so that I can see clearly the problem that I am facing. Second, I believe that whoever meditates at Sunan Tembayat's tomb will obtain help from Sunan Tembayat. After performing ziarah, I feel confident in dealing with my problem. Therefore, I see the meaning of barakab in terms of that feeling.

The oldest juru kunci of Bayat said that the significance of ziarah is that it provides motivation and courage to support people in achieving their goals. ${ }^{14}$ By performing ziarab people feel that God is behind them, and that provides strong motivation and confidence, which encourages them to pursue their goals. In this respect, the juru kunci interpret the meaning of barakah as 'arousing motivations' (ngundang semangat). While assisting during ziarab he often gives visitors a prayer (donga), to encourage visitor motivation:

"Bismillahi Arrabmani Arrabim, Oh, God, if my livelihood (rejeki) is still in the sky, would you please drop it to me. And if the rejeki is still in the earth, would you please extract it for me. If my rejeki is far away from me, would you please bring it close to me. And if my rejeki is unlawful (haram), would you please make it lawful (balal) for me. Amen."15

Differing interpretations of the meaning of barakab affect how visitors perceive the expression of barakah. Those who believe that barakah is given for mundane situations only symbolize barakab in mundane signs, such as in water, flowers, incense, rice from a slametan and so forth. However, those who believe in barakah that will be received on the day of judgment, do not symbolize barakab in worldly objects. If barakah is symbolized in terms of worldly objects, it might wrongly be understood that the objects themselves constitute barakah. The oldest juru kunci bridges the gap between these two extreme groups by saying that forms of barakah symbolized by water, flowers, incense and so forth are intended to be understood as providing motivation for visitors, evidence for visitors that they have obtained barakah. The status of having barakab does not rely upon the thing itself, but upon the belief that the object contains barakah.

A crucial question concerns the source of barakab. Where does it originate ? From God or Sunan Tembayat? Some visitors argue that barakab comes from Sunan Tembayat, whereas others argue that it derives from God. Visitors who identify Sunan Tembayat as the source of barakah address their prayers to him, while visitors who believe 
that God alone possesses barakah address their prayers to God. Those who believe that Sunan Tembayat can give barakah to visitors argue that as a wali, Sunan Tembayat has the right to give barakah. According to these visitors, Sunan Tembayat transmits barakab in two ways. First, he transmits barakah as a wali, believed to be an agent of God on earth who has been given the ability to provide barakah. People argue that wali have the ability to give barakab is because God has bestowed karamah (favor) on them. This karamab can include the ability to perform miracles granted by God. ${ }^{16}$ Because of this, wali are regarded as 'above human criticism'. They have the status of being the hand of God, God's representative to transmit barakah.

Second, barakah is transmitted as a part of Sunan Tembayat's barakah. To reward his piety and obedience in performing God's commands, Sunan Tembayat received barakab from God throughout his life and after his death. Therefore, he was filled with barakab and can transmit a part of his barakab to other people. A juru kunci offered the following an analogy of this way of transmitting barakab:

"Like a glass, when it is filled with water, it is full. When water is continuously poured into a full glass, the water will overflow. Similarly, we believe that Sunan Tembayat is already full of barakah because God continues to give him barakah although he is already dead. As Sunan Tembayat continues to receive barakah from God, his barakah overflows. Therefore, visitors search for the barakah that overflows (melimpah) from Sunan Tembayat. In addition, Sunan Tembayat does not need barakab any more. The barakah, then, is given to visitors who need it."

However, other visitors disagree with this view, and say that God alone owns barakah. Wali are only normal people who have no rights to give barakah. It is true that as a wali, Sunan Tembayat was very close to God, but it does not mean that Sunan Tembayat's closeness to God provides him with the right to give barakah. The Sunan Tembayat's closeness to God means two things. First, he is among the pious people who have been guaranteed their salvation on the day of judgment. Second, he can communicate with God. Therefore, Sunan Tembayat's closeness to God might be used by visitors to mediate in their communication with God, not to ask him for barakah. Performing ziarab to Sunan Tembayat's tomb is to seek his mediation to convey their messages to God asking for barakab.

Debates about the concept of barakab and the ways of transmitting barakab lead to discussion of different perceptions of Sunan Tembayat 
as a wali. Serat Babad Tembayat describes him as the Javanese wali (wali sanga) replacing Seh Siti Jenar who was condemned as a heretical Sufi. According to some peoples' beliefs, a wali is chosen in virtue of his/her sincere devotion, self-mortification and firm attachment to eternal realities. Wali is an Arabic term that has several meanings, those who are close to, those who protect, and those who rule. In Sufis terms, juru kunci in Bayat figure that the term wali alludes to individuals who are close to God, to people whose holiness takes them close to God, and who receive from Him miraculous gifts. The juru kunci cited a verse from the Qur'ân that describes wali as God's friends, "For friends of God (wali) no fear shall come and they shall not grieve” (Qur'ân, 10. 62). According to Bayat tradition, Sunan Tembayat was inaugurated as a wali by Sunan Kalijaga after he received a revelation (wahyu widayat $)^{17}$ on Friday Kliwon of 27th Ruwah ${ }^{18}$ (Soewignja, 1938:31).

Visitors to Bayat, regard wali as pious people (?âliłîn, plural, from ?âlił) who obey and practice religious teachings more than normal people do. Because of their piety, wali belong to the 'highest rank' (derajat tinggi). Moreover, visitors maintain that wali have a special relationship with God that makes them particularly well placed to serve as intermediaries to him. Wali are close to God. The meaning of "closeness" here is modeled upon, and to some extent constitutes a pattern for, relationships among people, such as next of kin, patron, protector and friend. These special positions of wali are strengthened by the fact that God gives them barakah expressed in terms of, following Westermarck, "a mysterious wonder-working force". On the basis of these factors people venerate wali not only during their life, but also after their death.

The relationship between humans and God operates similarly to the relationships between human beings. Javanese hierarchical relations also apply to their relations with supernatural beings. Visitors enlist Sunan Tembayat as a mediator because they believe that Sunan Tembayat has a higher rank than ordinary people. Therefore, he is better able to communicate with God. A question arises here: how do visitors in Bayat explain Sunan Tembayat's mediation (wasilab)?

Wasilab originates from an Arabic meaning 'mediation and/or mediator'. Sunan Tembayat, as a wasilah is a person who conveys a message to someone. In religious terms, Sunan Tembayat, as a mediator, is the one who conveys messages to God. However, visitors have different elucidation of the role of wasilab. Wasilab means medium, mediator and referee. Sunan Tembayat, as medium, functions as a vessel used 
to deliver messages to God. Visitors draw an analogy between a wasilah and a postman who acts as a medium for communication through correspondence. The communications actually occur only between the person who writes the letter and the person who receives the letter. Sunan Tembayat's mediation is like that of the postman who delivers the message. After the line of communication is open, visitors continue their communication by themselves. Visitors argue that they delegate the message to Sunan Tembayat because they believe that they cannot convey the message themselves since they are full of sins. Furthermore, they argue that people cannot guarantee that their messages are heard by God, but if they delegate them to Sunan Tembayat they have a hope that their donga will be heard.

Other visitors perceive Sunan Tembayat as a mediator who acts as God's representative (wakil). God gave Sunan Tembayat, through wabyu widayat, an authority to perform as His representative on earth. Therefore, Sunan Tembayat can give barakah to people because God has given him authority to do so. Finally, as a referee, Sunan Tembayat makes recommendations for people so that they are able to communicate with God. His karamah and barakab enable him to make the recommendation.

Different definitions of the meaning of barakab and of the role of Sunan Tembayat in the transmission of barakab show that ziarab is continuously re-figured by visitors to fit with changing social situations. These meanings of barakah are constructed as logical explanations of their behavior during ziarah rituals. For example, visitors who perform their ziarah by rubbing Sunan Tembayat's tomb explain that rubbing is a means of bridging the gap between their tangible, material and temporal existence and the unseen, spiritual world. Visitors also know that their rationales may differ from those of others; visitors maintain that peoples' explanation of their activities is formulated through their experiences. They also believe that although visitors differ in their practices and rationales, they have the same end. I examine ziarah not as a set of curiosities taken out of popular context but as living, vital important elements in the day-to-day lives of visitors and Bayat people.

\section{Semedi, Nenepi and Impen}

After performing ziarah, most visitors spend at least one night at the graveyard, waiting for a sign of barakah from Sunan Tembayat. Visitors spend this waiting time in various ways, the most popular 
being semedi (meditation), nenepi (meditation with special attitudes and procedures) and impen (dreaming). Each way is believed to be best performed in a certain place. For example, semedi is believed to be best conducted at the main building of Sunan Tembayat's tomb and in its surrounding areas, whereas nenepi is best performed somewhere considered to have certain spiritual powers, such as behind the mosque, at the remains (petilasan) of Sunan Tembayat's mosque and at the tombs of Sunan Tembayat's descendants. Dreaming, however, is best done in areas close to Sunan Tembayat's tomb.

Some visitors perform semedi by sitting with crossed legs (sila), with their arms folded across their chest (sedekep), and with eyes closed to maximize concentration. These visitors meditate at least all night long in a special place, such as in front of the long tomb located to the right of the main building of Sunan Tembayat, concluding when the cocks crow. These visitors select the places on the basis of reports that most visitors who meditate there receive ngalamat. However, not all visitors mediate at this place. The appropriate place to meditate depends on the purposes of ziarah. If visitors wish to gain ngalamat ensuring their success in business, it is suggested that they meditate in front of the tomb of the successful trader (juragan) Dampu Alam, Sunan Tembayat's treasurer. This tomb is located on the right side of the Sunan Tembayat's main building, side by side with the tomb of Ki Ageng Pawilangan, Sunan Tembayat's secretary. Visitors who wish to achieve career success are advised to meditate at the Ki Ageng Pawilangan, Sunan Tembayat's secretary. One visitor reported that he always received ngalamat relating to educational matters, career, and even to lottery numbers, every time he meditates at the Ki Ageng Pawilangan's tomb. Other people suggest meditating at the ruins (petilasan) of Sunan Tembayat's mosque at the top of the Jabalkat Hill in order to acquire physical power.

The second way of waiting for barakah, nenepi, is rarely performed because its requirements are very rigorous. For example, a visitor who wishes to acquire an amulet to attract a woman (pengasib) through nenepi should perform kungkum (immersing oneself in water) and pasa mutib (eating only white foods, such as rice) for three nights, and make offerings that consist of vegetables, chicken, fruits, jenang abang and jenang putih. Kungkum is conducted in the pool of Sunan Tembayat's wife, whereas offerings are made at her tomb. Afterward, the person meditates for at least three days at the tomb of Sunan Tembayat's wife. 
It is essential that nenepi procedures are not changed, because alterations will affect the outcome. Nenepi procedures are transmitted in oral traditions. Sometimes, people just recall the procedure of people who have succeeded in their nenepi. For example, the procedure for attracting a pengasih is based on the practice of following those who have succeeded in doing it. If people fail to acquire a pengasib by nenepi, then the failuris analyzed with a view to perfecting the nenepi. The factors analyzed include the seriousness with which nenepi is performed, and the completion of required preparations, such as offerings, flowers and incense. People believe that the nenepi should be performed perfectly. ${ }^{19}$

Impen is the most popular and the easiest way to await barakah. To have a dream is considered easy. However, in terms of the results, dreams offer the least hope of success because people do not always dream in their sleep. Some people also have difficulty in recalling the events that occur in a dream. Moreover, few people know how to interpret the signs (ngalamat) that are given in a dream. Some visitors prolong their ziarah and stay at the graveyard until they have dreams.

The place where people sleep is considered by some to be an important determinant of the kind of dreams they will have. Some visitors sleep near to certain tombs because they wish to receive a certain ngalamat. ${ }^{20}$ However, others do not believe that the place influences the ngalamat that will be obtained; wherever they sleep in the graveyard complex, they will have a good dream. They suggest choosing a place that is conducive to sleep. A nice sleep will encourage dreaming. Therefore, rather than sleeping at the main tomb, which is quiet, dark and scary, and which may disturb sleep, they prefer to sleep in the juru kunci's hall, which is pleasant and comfortable.

Compared to the other two ways of waiting for ngalamat, nenepi is the most difficult. Most people give up midway through the nenepi. However, in terms of results, nenepi often gives a direct result. A young man who wandered around the sacred tombs of Javanese wali recounted his experience:

"I was a motorbike racer, but only a regional racer. In the regional championship unfortunately I always failed at the final race. This is because those who contested at the final stage had a better amulet than I had. Previously I searched for an amulet to ensure safety, to protect my body from serious injury. However, after I discovered that some racers had an amulet to support their motorbike, I went to a kyai to search for such an amulet. The kyai asked me to conduct nenepi for at least a week at the corner outside his house. On the seventh day of 
my nenepi an old man approached me, and he struck my knee with his hands. I screamed because it was so painful. Afterward, the man gave me a glass of water. When I opened my eyes, there was no one beside me. Feeling scared, I ran into my kyai's house and told hirn what had just happened. Then he explained that a power had entered my body. The old man who struck my knee actually had introduced the power into my body. The kyai took a big stone and threw it at my knee, but I did not feel anything. The water, my kyai said, is for your engine. Just take a little amount of water into your wheel, it will fasten the motorbike. My kyai advised me, "Do not ever show your power to people". But, I did not take my kyai's advice, and I used my power to destroy my opponent's motorbike in front of a crowd of people. After that, my power disappeared, and my motorbike and legs were not protected any more. My leg was broken, and I never again contested a race."

According to some visitors, these three methods form a kind of hierarchy. If visitors obtain ngalamat through impen, they do not apply the other methods. If visitors do not get ngalamat while sleeping, it will be suggested that they meditate; and if they still do not obtain ngalamat through meditation, people will urge them to perform nenepi. However, other visitors argue that nenepi and semedi are improper ways of conducting ziarah. In these peoples' beliefs that these methods are not based on the right belief.

\section{Barakab and Peroleban}

Javanese visit not only the pious Islamic wali, but also other sites or objects that are believed to have spiritual power. The most popular sites are mountains, rivers, trees or special sites with a specific spiritual story, such as the sumur tiban ('fallen well') in the area of Ranggawarsita's graveyard. The well is called a 'fallen well' because, according to tradition, it was not made by humans, but fell from the sky. Some people perform nenepi at the well and bathe there in the middle of the night to obtain rejeki (livelihood).

In Bayat, visitors distinguish between the results obtained through ziarab to the pious Islamic wali and the results achieved through visits to other objects or places; the former are called barakah, the latter perolehan (a noun meaning 'something that is obtained from', deriving from oleh, meaning 'to get'). ${ }^{21}$ While barakah is considered to be good, perolehan is seen by some people as improperly acquired and thus harmful. ${ }^{22}$ This is because, according to some visitors, perolehan, e.g. pengasib (a means of attracting people), pesugiban (a means of accumulating wealth), and penglaris (a means of trading more successfully), are not acquired in the normal way. To obtain these 
perolehan one employs a devil. Even though it is true that perolehan can generate material wealth, it will not ensure true happiness. Barakah, however, helps people to achieve happiness.

People characterize barakah as 'good' for two reasons: its source and the means of acquiring it. Barakah is derived from wali, pious people rewarded by God for their dedication to God. Perolehan, however, is obtained through visiting sites that have no relation to God. The visit to these sites is associated with a visit to a supernatural power. Although it is true that perolehan derives from spiritual power residing in certain things, such as mountains and rivers, perolehan is not pure.

Barakab is considered to be good, since it is obtained in the right manner, such as by tablill, and by the normal way of conducting ziarah. Perolehan is obtained differently. A visitor described an example:

"Once my neighbor suggested that I search for peroleban at Mountain Kawi. ${ }^{23}$ He had gone to the mountain and he became rich. He obtained a pesugiban called a 'green giant' (buto ijo) from the mountain Kawi and was told that he had to feed the giant with special food. He never told me about the food that he had to give the giant. Villagers assumed that the giant was fed with children, because all my neighbor's children died at an early age. To obtain such a pesugiban at Mount Kawi, people have to enter a contract with the giant. The contract specifies the duration that the pesugiban will be possessed, the feeding requirements of the pesugihan and other requirements. Furthermore, people have to conduct a special meditation that consists of making offerings in special homage to the spirit who looks after the mountain (danyang), by making offerings such as their children, and fasting for fourteen days in the mountain area. The wealth gained from the pesugihan does not last long. Those who possess it often meet with an accident or die suddenly. My neighbor, for example, had his wealth destroyed by fire."

Different interpretations of barakah shape the entire discourse of ziarab. The concept of barakab becomes an 'ideological basis' for the explanation of ziarah. Visitors base their logical explanation for performing a certain procedural ziarah on their particular concept of barakah. Peoples' explanation of perolehan can be seen in two ways. First, visitors in Bayat believe that ziarab to any place will provide results. Second, the concept of perolehan is provided to distinguish between good and bad barakah achieved through ziarah. Third, perolehan and barakab are used to give a distinctive value to ziarab to pious Islamic wali.

In spite of this debate concerning the differences between barakah 
and perolehan, there are some people who argue that the result of ziarah is not expressed in terms of baraka or perolehan explained above. They believe that the ziarah is a journey to get peace (ketentreman) and wisdom (waskita). These people visit Sunan Tembayat's tomb to seek peace and wisdom, not baraka and peroleban.

\section{Cocok and Ikbtiar}

Visitors who perform ziarah at the Bayat grave complex come from all over Java, even from outside Java. Some visitors argue that their ziarab is a programmatic zi, involving visits to all the pious wali throughout Java. Their visit to Sunan Tembayat's tomb, therefore, is a part of that long journey. During their visits they conduct ziarah with tahlîl, reciting the Qur'ân, meditating and so forth. The aim of the programmatic ziarah, some visitors point out, is to find eternal wisdom and an heirloom.

However, some visitors argue that their ziarab is an effort (ikbtiar) to improve their lives. These visitors assert that their ziarab to Sunan Tembayat's tomb is not part of a programmatic ziarah, but rather is intended to find the place most personally appropriate (cocok) for ziarah in order to achieve their goals. One visitor from Demak preferred to visit Sunan Tembayat's tomb, which is quite far from Demak, rather than to visit Sunan Kalijaga's tomb, which is closer, because he felt more cocok performing ziarah at Sunan Tembayat's tomb.

The concept of cocok in ziarab is important. Not only does this concept explain the failure of visitors' ziarab to certain places, but also it provides a legitimization of ziarab beliefs. Visitors often compare with each other methods of performing ziarah, including requirements for ziarah, donga, their intentions and their methods of awaiting ngalamat. However, in some cases, visitors may perform the ziarab in exactly the same manner and using the same methods, but achieve different results. In such cases, visitors may doubt the success of their ziarah. The concept of cocok plays an important role in rebuilding peoples' confidence in their ziarah. A juru kunci explained:

"Many people come to me asking for a logical explanation of their ziarah because they doubt that they can obtain baraka from their ziarab since many of them have obtained nothing though they may have completed the ziarah. Of course, I give a different explanation to different people. For people who have a strong Islamic background, I say that we humans cannot determine the success 
of our efforts. Although humans have carried out their efforts, they cannot guarantee their success, but only God does. Thus, ziarah is a prayer addressed toward God to obtain success. However, for people who do not have a strong Islamic background, I choose rather to use the Javanese concept of cocok. If a visitor succeeds in his/her ziarab in Sunan Tembayat's tomb that means that the place is cocok for him/her, but if another fails to gain any ngalamat from Sunan Tembayat's tomb, it means that the place is not cocok. Therefore, if a visitor fails to obtain baraka from a certain wali's tomb, he/she should wander to other walis' tombs to find the cocok place."

Javanese sometimes interpret cocok as referring to the concept of jodo(b) (suitable or partner). If a person becomes sick and does not recover after taking a certain medication, while another person with the same sickness and taking the same medicine does recover, it means that the medicine is not jodo for the first person, while it is for the second. If a person fails to marry her/his fiancée though they have been engaged for a long time, it means that they are not jodo. If a person is given a heirloom and suddenly becomes sick, it means that the heirloom is not jodo for that person. If a person makes an offer for land but fails to negotiate a good price, it is said that the land is not jodo for him. Therefore, when visitors do not gain ngalamat from Sunan Tembayat it is because the place is not jodo for them.

Visitors to Bayat consider many potential causes of ziarah failures, such as the procedures used in performing ziarah, the comprehensiveness of meeting ziarab requirements, the reciting of the donga, and the intention. If they do not find anything amiss in these areas, they return to the concepts of cocok and jodo. Juru kunci argue that the concepts of cocok and jodo play important roles in building visitors' feelings of equanimity (ikblas). Referring to cocok and jodo visitors can accept any result of ziarah with equanimity .

To sum up, the ziarah ritual is sometimes portrayed as an autonomous activity distinct from particular religious ideas. The emergence of various forms of ziarah discourse result from peoples' diverse understandings of the meaning of baraka. The whole structure of discourse concerning the concept of baraka among juru kunci and visitors serves primarily to answer the questions posed by visitors and juru kunci to provide a cultural logic for their ziarab. This in turn influences the way that people rationalize the results of their ziarah. Visitors to Bayat explain baraka in terms of material and spiritual qualities. Furthermore, the concept of baraka is influenced by the social context in which the concepts of baraka are formulated. 


\section{Endnotes}

1. Visitors, who have visited Bayat seven times, will hold a hajat slametan to symbolise it, as it is believed that the seventh visit to Sunan Tembayat is very important. A hajat slametan is performed to celebrate the reception of baraka from the Sunan. A visitor who feels that he has received baraka from Sunan Tembayat is obligated to conduct a slametan as a way of showing his thanks to the Sunan Tembayat. The hajat slametan, as implied by the designation, hajat, 'intention', is performed to declare the intention of ziarah.

2. This Javanese system is called Pasaran, deriving from pasar, meaning 'market'. This system is named Pasaran because it is used to indicate markets. For example, a market on Pahing day will busy with animal trade, whereas on Kliwon the market will sell vegetables and so forth. The Pasaran consists of five days, Wage, Kliwon, Legi, Pabing and Pon.

3. The petungan is also used by Javanese thieves. For example, on a Friday Kliwon night, the thief should enter by the rear door, on another day through the window and, on yet another, should not enter the house before 12 o'clock midnight. The chief of a small village in western Klaten was known as a thief catcher, because he knew the thieves' use of petungan.

4. To differentiate whether a person dreams at the middle of the night or at the meaning, people in Bayat consider the time when the person awakes from the dream. They believe that usually people awake after having a dream.

5. In Morocco, for example, where the traditions of Sufism is sustained, the Maraboutism tradition practice the herediterical concept of transforming a status. A Marabout in a certain zawiya (lodge) obtains his status from his father. The first Marabout, like Sheikh Lusi in Atlas, claimed his maraboutic status by linking him with the Prophet Muhammad and his families, the Sharif families.

6. Garebeg is a ceremony held three times a year: once to commemorate the birth of Prophet Muhammad (Garebeg Mulud), once to celebrate the end of the month of fasting (Garebeg Syawal); and once to solemnise the day of sacrifice (Garebeg Besar). Garebeg Mulud is conducted on a larger scale every eight years. In these garebeg, the sacred pusaka of Yogyakarta court are paraded and shown to the public (Soelarto, 1993).

7. The smoke of incense also can be used to repel mosquitoes. This need is evident in the places where visitors conduct their meditations. They mostly conduct their meditations, or nenepi, in a quiet place, such as on a mountain, at a river, or in the jungle where insects abound. In Bayat, for example, there is a special place to meditate on the top of Mount Jabalkat, which is full of mosquitoes. There are some warung (little shops) near the location that sell mosquito repellent. Some visitors do not buy the formula, because they use incense to repel mosquitos.

8. In Java cocok has more meanings than simply 'suitable'. If a woman gets married to a man and they live happily, it means that they are cocok. If a person takes medicine and he recovers, the medicine is cocok. If a person, after changing his/ her name is always sick, it signifies that the name is not cocok. If a visitor brings a flower for his ziarah and he does not gain baraka, it could be because the flower is not cocok.

9. The word baraka(h), derives from Arabic alphabet the ba-ra-ka-h. Arabic word which end with h (tak marbutab) are adopted into Javanese either with ' $h$ ' or ' $t$ ', such as berkat or berkah, and rahmat or rabmah. 
10. In studying Maraboutism in North Africa, anthropologists, such as EvansPritchard, Gellner, Gilsenan, Eickelman, Trimingham, Geertz and others, argue that baraka is 'God's blessing' which make the people who have it particularly well placed to serve as intermediaries with the supernatural and to communicate God's grace to the people (Evans-Pritchard, 1949; Gellner, 1969; Eickelman, 1976; Gilsenan, 1973).

11. This understand is also found in other Muslim regions, such as North Africa. There Evans-Pritchard, Gellner, Eickelman, Gilsenan and others also found the same tendency to interpret baraka as applying to mundane qualities.

12. He is a kyai respected by the juru kunci and the Bayat community. He always prays at official ceremonies held in Bayat, such as pasang singep and sadranan.

13. Ibadah derives from Arabic ibadah (worship to Allah). In Islamic terms the word ibadah signifies 'every action which is good and based on the worship to God.' The actions which are considered as ibadah will have a reward from Allah.

14. This view resembles Malinowski's discussion of magic and religion in which he maintained that, "those who are well acquainted with some good magic have, in virtue of that, courage and confidence".

15. "Bismillabi Arrahman Arrahim. Duh Gusti Allah, sak menawi rejeki kula menika tasih gumantung wanten ing langit, mugi Allah kersa nurunaken, lan menawi rejeki kula tasih sumimpen wanten ing njera bumi, mugi Allah kersa angedalaken, lan mbak menawi rejeki kula menika tebib kaleh papan panggenan kula, mugi Allab kersa nyedakaken, lan mbak bilih rejeki kula menika haram, mugi Allab kersa nyucekaken." This prayer is always recited by the Kyai of Bayat whenever he recites prayers at ceremonies such as the pasang singep and sadranan.

16. There is a controversy in differentiating between miracles performed by a wali and miracles by the Prophet. Some Sufi argued that a wali's miracles actually trickle from the Prophet's miracles, like 'a drop trickling from a full skin of honey' (Nicholson, 1989: 129).

17. Widayat is a Javanese term for bidayat, meaning a direction (petunjuk). This word is used by Muslims to refer to a kind of revelation given to a person who embraces Islam and becomes a serious Muslim. For example, a non-Muslim who converts to Islam is said to have received revelation (bidayat in Arabic and Widayat in Javanese). A Muslim who does not seriously obey Islamic teachings, and then becomes serious about practicing Islam, is regarded to have receiving bidayah.

18. Ruwah is the seventh Javanese month. The Javanese months are Sura, Sapar, Mulud, Ba'da Mulud, Jumadilawal, Jumadilabir, Rejeb, Ruwah, Pasa, Sawal, Dulkangidah and Besar (Except for Ruwah, Pasa and Besar these terms are derived from the Islamic lunar calendar. Some juru kunci speculate that Pasang Singep ceremony is conducted during Ruwah, in part, to commemorate the day of Sunan Tembayat's revelation.

19. This calls to mind Malinowski's discussion of the effectiveness of magic in Trobriand Islanders. People on the island analyse the failure of magic through the imperfection of the magic preparation, including the spell, requirements of performing magic and so forth.

20. Sleeping at Sunan Tembayat's main building is forbidden. Therefore, on the busiest nights some visitors take the opportunity to sleep for a while at the main building while the juru kunci are busy assisting other visitors.

21. People even distinguish between the results achieved through ziarah in Bayat areas. Some say that ziarah to Sunan Tembayat's wife and Sunan Tembayat's 
friends, Seh Kewel and Seh Domba perolehan.

22. Some people, however, do not see peroleban negatively. Some people seriously pursue them. In Bayat, a rich family is obligated to assure other people that their wealth is not achieved through perolehan. When I chat with a villager, he described his success, including his ability to educate all their children in the big cities, Jakarta and Yogyakarta. He assured me that he never employed peroleban. He further explained that in Bayat, if there were a successful family, there would be rumour that the family employs perolehan. One visitor from Magelang explained that it is a shame if a family is known to have a peroleban.

23. This mountain is considered to be a place to acquire pesugihan (a means of gaining wealth). 


\section{Bibliography}

Barber, R. 1991. Pilgrimages. Woodbridge: The Boydell Press.

Bell, Catherine. 1992. Ritual Theory, Ritual Practice. London: Oxford University Press.

Clancy-Smith, J.A. 1990. "Between Cairo and the Algerian Kabylia: The Rahmaniya tariqa, 1715-1800", in Eickelman, D.F. and James Piscatory (Eds.). 1990. Muslim Travellers: Pilgrimage, Migration, and the Religious Imagination. London: Routledge.

Cohen, Erik. 1992. "Pilgrimage Centers: Concentric and Excentric", Annals of Tourism Research, Volume 19, Number 1.

Darusuprapta, et. all. 1974. Laporan Penelitian: Kekunaan di Bayat Klaten. Yogyakarta: Fakultas Sastra dan Kebudayaan Universistas Gadjah Mada.

Dhofier, Z. 1982. Tradisi Pesantren. Jakarta: LP3ES.

Eickelman, D.F. 1976. Moroccan Islam: Tradition and Society in a Pilgrimage Center. Austin and London: University of Texas Press.

_ 1990. "Preface" in Eickelman, D.F. and James Piscatory (Eds.) 1990. Muslim Travellers: Pilgrimage, Migration, and the Religious Imagination. London: Routledge.

1990. "Social Theory in the Study of Muslim Societies", in Eickelman, D.F. and James Piscatory (Eds.). 1990. Muslim Travellers: Pilgrimage, Migration, and the Religious Imagination. London: Routledge.

Eickelman, D.F. and James Piscatory (Eds.). 1990. Muslim Travellers: Pilgrimage, Migration, and the Religious Imagination. London: Routledge.

Evans-Pritchard, E.E. 1949. The Sanusi of Cyrenica. London: Oxford University Press.

Fox, J.J. 1991. "Ziarah Visits to the Tombs of The Wali, The Founders of Islam on Java", in Ricklefs, M.C. 1991. Islam in the Indonesian Social Context. Clayton: Center of Southeast Asian Studies, Monash University.

Geertz, Clifford. 1976. The Religion of Java. Chicago: The University Chicago Press. Gellner, E. 1969. Saints of The Atlas. London: Weidenfeld and Nicholson.

Gilsenan, M. 1973. Saints and Sufi in Modern Egypt: An Essay in the Sociology of Religion. Oxford: Clarendon Press.

Groom, Nigel. 1981. Frankincense and Myrrb: A Study of the Arabian Incense Trade. London and New York: Longman.

Hodgson, M. The Venture of Islam: Conscience and History in a World Civilization. Chicago: University of Chicago Press.

Leach, E.R. 1979. Dialectic in Practical Religion. Cambridge: Cambridge University Press.

Masud, Muhammad Khalid. 1990. "The Obligation to Migrate: The Doctrine of bijra in Islamic Law", in Eickelman, D.F. and James Piscatory (Eds.). 1990. Muslim Travellers: Pilgrimage, Migration, and the Religious Imagination. London: Routledge.

Morris, Brian. 1987. Anthropological Studies of Religions. Cambridge: Cambridge University Press.

Nicholson, R.A. 1989. The Mystics of Islam. London: Arkana, Victoria.

Pranowo, B. 1991. "Traditional Islam in Contemporary Rural Java: The case of Tegal Rejo Pesantren", in Ricklefs, M.C. 1991. Islam in the Indonesian Social Context. Clayton: Center of Southeast Asian Studies, Monash University.

Ricklefs, M.C. 1979. "Six Centuries of Islamization in Java", in Levtsion, Nehemia 1979. Conversion to Islam. New York and London: Holmes \& Meir Publisher. 
Salam, Solichin. 1960. Sekitar Wali Sanga. Kudus: Menara.

Soelarto, B. 1993. Garebeg di Kesultanan Yogyakarta. Yogyakarta: Kanisius.

Soewignja. 1938. Kjai Ageng Pandanarang. Batavia-C: Bale Poestaka.

Trimingham, J.S. 1971. The Sufi Orders in Islam. Oxford and London: Oxford the Clarendon Press.

Turner. 1974. Dramas, Fields, and Metaphors: Symbolic Action in Human Society. Ithaca and Lond: Cornell University Press.

, V. 1974. "Pilgrimage as Social Processes", in Turner. 1974. Dramas, Fields, and Metaphors: Symbolic Action in Human Society. Ithaca and London: Cornell University Press.

Turner, V. and Edith Turner. 1978. Image and Pilgrimage in Christian Culture: Anthropological Perspectives. Oxford: Basic Blackwell.

Woodward, M. 1989. Islam in Java: Normative Piety and Mysticism in the Sultanate of Yogyakarta. Tucson: The University of Arizona Press.

Jamhari is a lecturer at the Postgraduate Studies IAIN Syarif Hidayatullab Jakarta. 